\title{
The Occupation of Benzú Cave (Ceuta) by Neolithic and Bronze Age Societies
}

\author{
Eduardo Vijande-Vila (iD • Juan Jesús Cantillo-Duarte • José Ramos-Muñoz • \\ Darío Bernal-Casasola • Salvador Domínguez-Bella • Sergio Almisas Cruz • \\ Ignacio Clemente-Conte • Niccolò Mazzucco • Mila Soriguer-Escofet • \\ Blanca Ruiz Zapata • María José Gil • Paloma Uzquiano • Débora Zurro • \\ José Antonio Riquelme • Antonio Sánchez Marco • Antonio Rosas • Almudena Estalrich • \\ Marcus Bastir • David Cuenca-Solana • Adolfo Moreno-Márquez • \\ Renata Martínez-Cuesta $\cdot$ Pablo Ramos-García
}

(C) Springer Science+Business Media, LLC, part of Springer Nature 2019

\begin{abstract}
This study presents the results of the archaeological investigation in Benzú Cave, located on the North African shore of the Strait of Gibraltar. The archaeological deposits, approximately $1 \mathrm{~m}$ deep, belong to two occupational levels dated to the Neolithic and the Bronze Age. A wide range of artifacts was found, and this led to an interdisciplinary study that led us to reach new conclusions concerning the material life, subsistence economy, and environment of the Neolithic and Bronze Age societies in northern Africa and the southern Iberian Peninsula.
\end{abstract}

Résumé Cette étude présente les résultats des recherches archéologiques menées dans la grotte de

E. Vijande-Vila $(\bowtie) \cdot J$. J. Cantillo-Duarte •

J. Ramos-Muñoz $\cdot$ D. Bernal-Casasola •

S. Domínguez-Bella $\cdot$ S. A. Cruz · M. Soriguer-Escofet •

A. Moreno-Márquez

Universidad de Cádiz, Cádiz, Spain

e-mail: eduardo.vijande@uca.es

I. Clemente-Conte $\cdot$ N. Mazzucco $\cdot$ D. Zurro

Institució Milá i Fontanals-CSIC, Barcelona, Spain

B. Ruiz Zapata • M. J. Gil

Universidad de Alcalá de Henares, Madrid, Spain

P. Uzquiano

Universidad Nacional de Educación a Distancia, Madrid, Spain

J. A. Riquelme

Universidad de Córdoba, Córdoba, Spain
Benzú, située sur la rive nord-africaine du détroit de Gibraltar. Les gisements archéologiques, d'environ un mètre de profondeur, appartiennent à deux niveaux d'occupation datant du néolithique et de l'âge du bronze. Une large gamme d'artefacts ont été trouvés, ce qui a conduit à une étude interdisciplinaire qui nous a amenés à tirer de nouvelles conclusions concernant la vie matérielle, l'économie de subsistance et l'environnement des sociétés du Néolithique et de l'Age du Bronze en Afrique du Nord et au sud de la Péninsule Ibérique.

Keywords Benzú Cave · North Africa · Neolithic · Subsistence $\cdot$ Bronze Age

\section{A. Sánchez Marco}

Institut Catalá de Paleontología Miquel Crusafont, Barcelona, Spain

A. Rosas · A. Estalrich · M. Bastir

Museo Nacional de Ciencias Naturales, CSIC, Madrid, Spain

D. Cuenca-Solana

Instituto Internacional de Investigaciones Prehistóricas de Cantabria, IIIPC-Gobierno de Cantabria, Universidad de Cantabria, Santander, Spain

D. Cuenca-Solana $\cdot$ R. Martínez-Cuesta

Universidad de Cantabria, Santander, Spain

P. Ramos-García

Universidad de Granada, Granada, Spain 


\section{Introduction}

The study of North African Neolithic societies has made progress over the last few decades building on the foundations laid in the early to mid-twentieth century. The Tingitana Peninsula in northern Morocco was the focus of some of those earlier studies (e.g., Gilman 1975; Howe and Movius 1947; Koehler 1931; Tarradell 1954, 1958a, b). Several interdisciplinary archaeological projects, including palynological and chronometric studies, have provided the data needed to develop a periodization scheme and explanatory models for the peninsula's settlement history (Daugas and El Idrissi 2008; Daugas et al. 1989, 1999, 2008; Martinez Sanchez et al. 2018). Those studies show that the Neolithic occupation of the region had a pre-Cardial ceramic phase during the sixth millennium BCE, defined by the appearance of ceramic decorations that were influenced by styles prevalent in nearby Algeria. Paleobotanical evidence collected in such sites as Caf Taht el Ghar also suggests agricultural practices characterized by the cultivation of cereal like wheat (Triticum sp.), emmer (Triticum dicoccum), free-threshing wheat (Triticum aestivum/durum), and legumes (Vicia faba) (Morales et al. 2016). Agricultural practices were carried out with knapped stone tools (blades and sickles) and polished stone tools. Another phase in this Early Neolithic period was the development of Cardial ceramics, characterized by impressed decorations with cardium or denticulated shell, a phenomenon that is common in other parts of the Mediterranean region. The following Middle Neolithic period was dominated by El Kiffen-type ceramics (comb motifs) and Ashakar-type ceramics, characterized by impressed linear, circular, and cord-wrapped motifs (Martinez Sanchez et al. 2018, p. 423). The Late Neolithic Phase is not well known.

In 1989, Wengler et al. (1989) developed a synthesis of the Neolithic period in eastern Morocco (Eastern Rif), arguing that Neolithic societies in this region had been chiefly pastoral. In the late 1990s, a German-Moroccan project working in the Eastern Rif presented a series of contexts for the understanding of the Neolithic period in northern Morocco. These contexts included evidence for the transitions between Epipaleolithic groups with ceramics and Neolithic groups (for instance, in Hassi Ouenzga), and for the early development of agricultural practices around $5600 \mathrm{BCE}$ (in Ifri Oudadane) in a typical Western Mediterranean Neolithic tradition (Linstädter 2008, 2011, 2016; Mikdad et al. 2000;
Morales et al. 2013; Nekkal 2015). There were also various research projects in the Middle Atlas (Mikdad et al. 2012) and Upper Atlas (Raynal 2008; Ruiz-Gálvez et al. 2012) which indicate contacts with the Saharan region, from the fifth/fourth millennium onwards (Linstädter 2016). Concerning the final Neolithic, postdepositional disturbances have severely affected the preservation of the third- and second-millennia contexts. Some noteworthy exceptions are the upper levels of Gar Cahal, dated by thermoluminescence (TL) to the turn of the second millennium BCE (Daugas et al. 1999). The surface finds at Oued Moulouya, in the Eastern Rif, have also yielded some Late Neolithic occupation levels (Linstädter et al. 2012).

Several studies have emerged in the past decade that examine the cultural and demographic relationships between Epipaleolithic and Neolithic groups (Linstädter 2008); the economic characteristics of the early Neolithic groups, specifically the adoption of farming and pastoral economies (Nekkal 2015); the impact of environmental change on cultural practices (Linstädter 2016); and issues of periodization and cultural history. All of these studies highlight the need to define Neolithic ways of life and socioeconomic practices accurately and to track their evolution over time. This paper is a contribution to this effort, focusing on Benzú Cave, a site located in the northernmost tip of the Tingitana Peninsula (Ramos Muñoz et al. 2013).

\section{Benzú Cave: Location, Stratigraphy, and Chronology}

Benzú Cave is located on the African shore of the Strait of Gibraltar, in western Ceuta (Fig. 1). The cave is barely $25 \mathrm{~m}^{2}$ in size and is divided into two chambers. The archaeological deposits, approximately $1 \mathrm{~m}$ deep, consist of fine sands and include two occupational levels: Late Neolithic and Early Bronze Age (Fig. 2). Excavations were undertaken annually from 2002 to 2005 and in 2007. In total, we excavated twenty-one $1 \times 1-\mathrm{m}^{2}$ units. These have enabled us to map the different areas of activity in the cave, identify production and consumption processes, and improve our understanding of the inhabitants' ways of life. Although Benzú Cave is not large, it has yielded a wide array of archaeological evidence that, as we shall show below, shed new light on the ways of life of Neolithic communities in North Africa. 


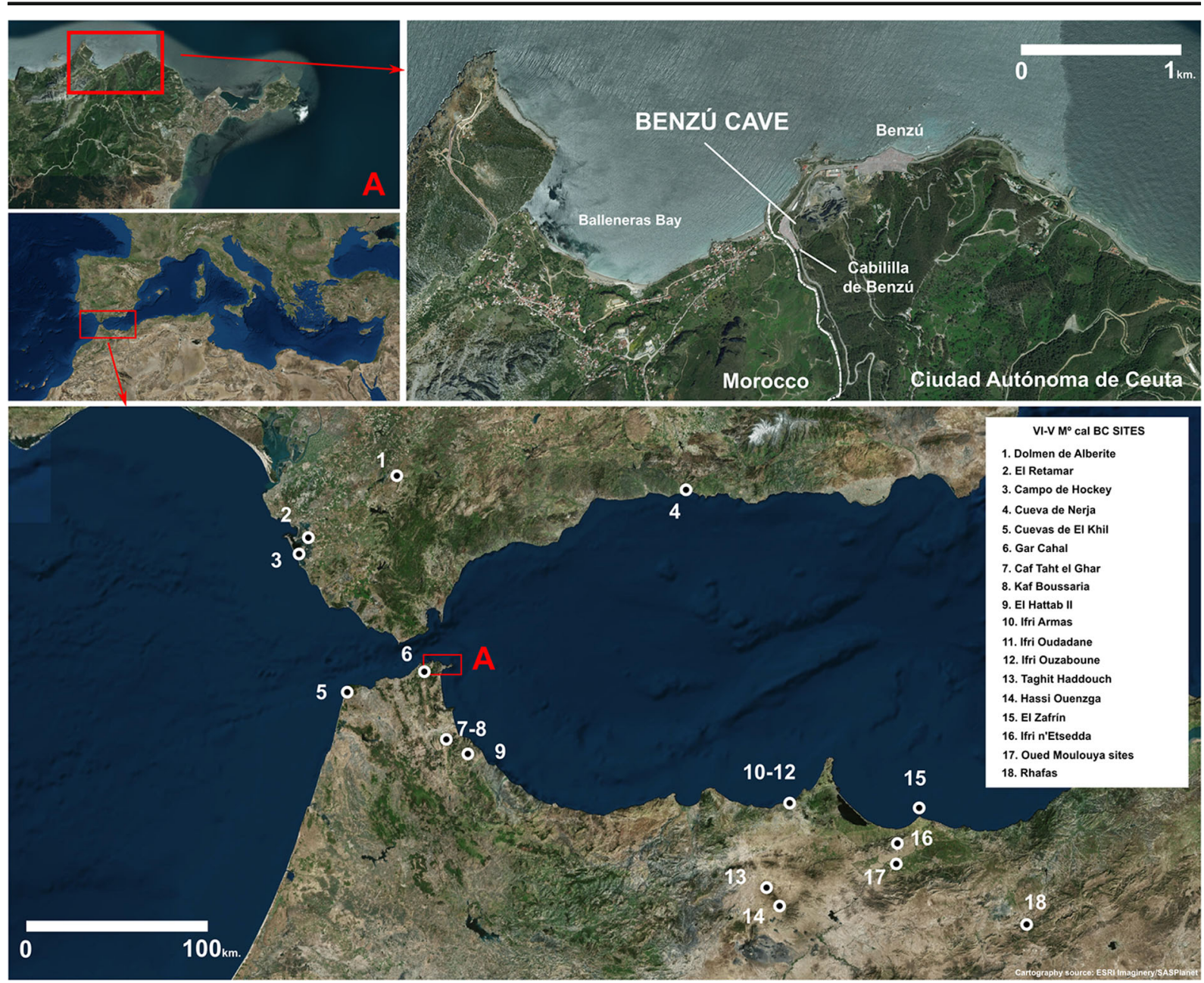

Fig. 1 Location of Benzú and other sites dated to the sixth-fifth millennia BCE in the Strait of Gibraltar

The stratigraphy of the cave is uniform in all of the excavated units (Fig. 2):

Surface level: Contemporary materials; the cave often served as a shelter for Europe-bound immigrants. Stratum II: Fine-grained sandy level, of a dark brown color (Munsell Color 10YR, 3/4). This level yielded abundant lithic and ceramic materials, as well as animal bones, shells, seeds, and other botanical remains. TL dating of a ceramic fragment from stratum II yielded a date of late sixth millennium BCE, Neolithic period. Although this stratum II is dated to the Neolithic, some squares (AXVIIXVIII, -AXVIII-XIX, AXVIII-XIX, -AXIX-XX, AXIX-XX, and AXX-XXI; Fig. 3) have yielded bone remains and personal ornaments related to a secondary burial. The $\mathrm{C} 14$ dates of a human bone and tooth in stratum II suggest that the site was reused for burial during the Bronze Age, at the turn of the second millennium BCE (Table 1).

Stratum I: It is a thin fine-grained sandy level, of a dark gray color (Munsell Color 10YR, 3/1). This level is identified in only a few squares (AXIX-XX, AXIX-XX, -AXX-XXI, and CXVIII-XIX, Fig. 3). The finds are similar to those found in stratum II. This level is dated to the sixth millennium BCE.

\section{Methodology and Results}

In order to collect as much information as possible about the occupants of the cave and their subsistence 
Fig. 2 Plan and stratigraphy of the cave

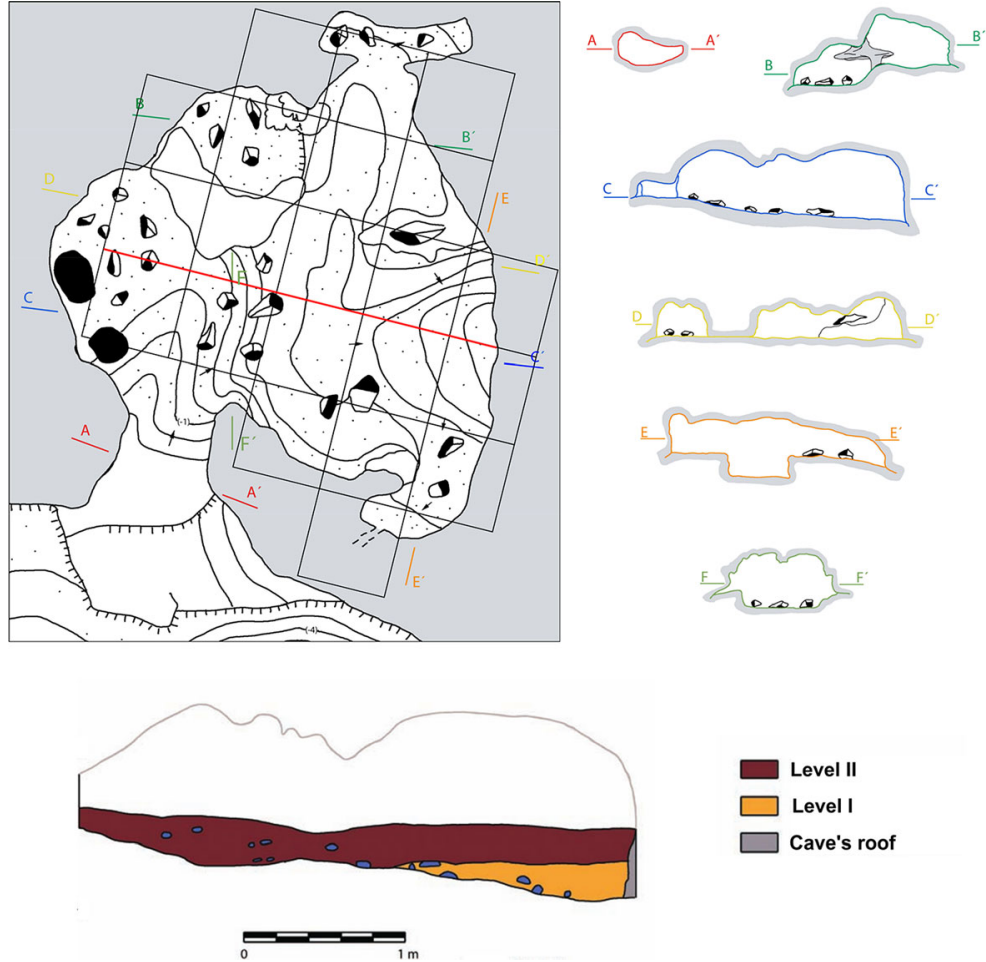

economy, an interdisciplinary team carried out a variety of analyses on the recovered artifacts, in addition to obtaining chronometric dates that established the chronology of the site. Terrestrial and maritime faunal remains were studied, and pollen and anthracological analyses were carried out to understand humanenvironment interactions and reconstruct past climatic conditions. The provenance of lithic materials was undertaken to establish the raw material supply systems and shed some light into human mobility and social network patterns. The technological and functional analyses of the lithic industry, ceramics, and malacofauna were carried out to determine the activities that were carried out inside the cave. Finally, we studied the human remains in Benzú Cave to make inferences about the nature of life and death of the individuals that occupied the cave during the Bronze Age.

\section{Pollen Analysis}

We collected sediments from both strata in units AXVIIXVIII, AXVIII-XIX, and -AXIX-XX for pollen studies (see Fig. 3). The extraction of pollen particles and residue concentrations followed the standard protocols (Coûteaux 1977; Goeury and de Beaulieu 1979). The results of the pollen analysis suggest a homogeneous vegetation landscape in both strata, characterized by an open evergreen landscape and Mediterranean vegetation. A small number of tree taxa are representedPinus sp., Cedrus sp., Quercus perennifolio, Quercus caducifolio, Ceratonia siliqua, Olea sp., Salix sp., Alnus sp., Ulmus sp., and Celtis sp. The prevalence of xeric (Asteraceae-liguliflorae and tubuliflorae-and Poeaceae) and steppic grass taxa (Artemisia, Chenopodiaceae, and Ephedraceae) along with the smaller presence of riverine taxa also indicate drier conditions. The pollen profile is indicative of a greater anthropic pressure upon the landscape, exemplified by the predominance of ruderal and grassland taxa, as well as by the constant and progressive increase of nitrophile taxa, which points toward the increasing nitrification of soils (Table 2). It is also important to point out the presence of Asphodelus spp., which is associated with fire episodes (Fig. 4).

\section{Anthracological Evidence}

Charcoal samples were collected by manual flotation, wet sediment sieving (using different mesh sizes depending on sediment fraction). The process was systematic, 


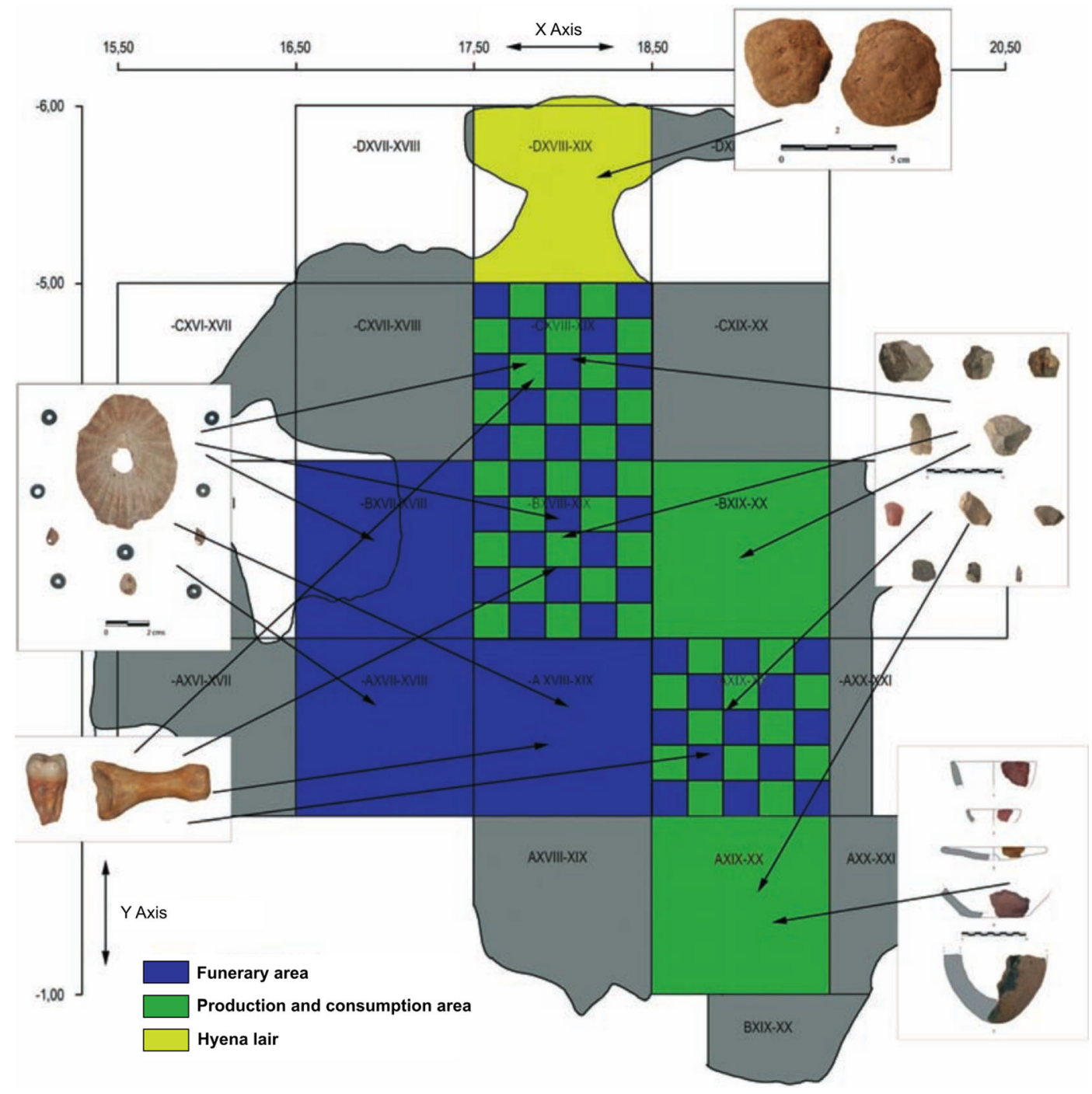

Fig. 3 Activity areas in Benzú Cave

involved the processing of $100 \%$ of the excavated sediment, and followed the protocols that Uzquiano (1992, 1997, 2006) has established. The coastal location of the site and its exposure to oceanic winds was a significant factor in the predominance of woody shrub vegetation in the anthracological samples (Table 3; Uzquiano 2008). The charcoal samples indicate that the following tree species, Quercus ilex-coccifera (hermes oak), Quercus suber (cork oak), Quercus canariensis (gall oak), Fraxinus angustifolia (ash), Salix pedicellata

Table $1 \mathrm{TL}$ and ${ }^{14} \mathrm{C}$-AMS dating. Radiocarbon dates have been calibrated with $\mathrm{OxCal} 4.3 .2$ and IntCal 13

\begin{tabular}{|c|c|c|c|c|c|c|c|c|}
\hline Site & Context & Sample & Stratum & Dating system & BP date & $\begin{array}{l}\text { Cal BC date } \\
\text { (2) }\end{array}$ & Laboratory & $\begin{array}{l}\text { Bibliographic } \\
\text { reference }\end{array}$ \\
\hline Benzú & -AXIX-XX-2 & Pottery & II & $\begin{array}{l}\text { Thermoluminescence } \\
\text { (TL) }\end{array}$ & $7136 \pm 433$ & - & MAD-3076 & $\begin{array}{l}\text { Millán and Benéitez } \\
\text { (2003, p. 347) }\end{array}$ \\
\hline Benzú & -DXVIII-XIX 11 & Bone & II & ${ }^{14} \mathrm{C}-\mathrm{AMS}$ & 3622 & $2121-1894$ & OxA-23216 & Unpublished \\
\hline Benzú & -CXVIII-XIX 56 & Tooth & II & ${ }^{14} \mathrm{C}-\mathrm{AMS}$ & 3629 & 2127-1902 & OxA-23217 & Unpublished \\
\hline
\end{tabular}


Table 2 Stratigraphic distribution of flora, Benzú Cave

\begin{tabular}{|c|c|c|c|c|c|c|c|c|c|}
\hline \multirow{2}{*}{$\begin{array}{l}\text { Depth }(\mathrm{cm}) \\
\text { Sample }\end{array}$} & \multicolumn{5}{|c|}{ Stratum II } & \multicolumn{4}{|c|}{ Stratum I } \\
\hline & $\begin{array}{l}5.0 \\
\text { Cbn-5 }\end{array}$ & $\begin{array}{l}12.0 \\
\text { Cbn-12 }\end{array}$ & $\begin{array}{l}18.0 \\
\text { Cbn-18 }\end{array}$ & $\begin{array}{l}24.0 \\
\text { Cbn-24 }\end{array}$ & $\begin{array}{l}30.0 \\
\text { Cbn-30 }\end{array}$ & $\begin{array}{l}32.0 \\
\text { Cbn-32 }\end{array}$ & $\begin{array}{l}36.0 \\
\text { Cbn-36 }\end{array}$ & $\begin{array}{l}40.0 \\
\text { Cbn-40 }\end{array}$ & $\begin{array}{l}47.0 \\
\text { Cbn-47 }\end{array}$ \\
\hline Pinus & 8 & 16 & 12 & 4 & 7 & 0 & 0 & 0 & 0 \\
\hline Cedrus & 0 & 0 & 0 & 9 & 8 & 0 & 0 & 4 & 0 \\
\hline Quercus-p (perennifolio) & 0 & 3 & 3 & 7 & 0 & 9 & 8 & 3 & 9 \\
\hline Oleaceae & 12 & 33 & 4 & 3 & 27 & 21 & 4 & 15 & 13 \\
\hline Celtis & 11 & 21 & 0 & 0 & 0 & 0 & 0 & 0 & 0 \\
\hline Ceratonia & 0 & 0 & 31 & 0 & 0 & 0 & 0 & 0 & 0 \\
\hline Quercus-c (caducifolio) & 4 & 4 & 0 & 5 & 9 & 0 & 0 & 0 & 0 \\
\hline Betula & 0 & 0 & 0 & 0 & 0 & 0 & 0 & 0 & 0 \\
\hline Juglans & 0 & 0 & 0 & 0 & 0 & 0 & 0 & 0 & 0 \\
\hline Alnus & 5 & 0 & 4 & 0 & 0 & 8 & 0 & 4 & 4 \\
\hline Salix & 3 & 0 & 15 & 12 & 0 & 17 & 13 & 13 & 7 \\
\hline Ulmus & 0 & 0 & 0 & 0 & 0 & 4 & 0 & 9 & 0 \\
\hline Juniperus & 25 & 9 & 13 & 35 & 4 & 11 & 11 & 15 & 25 \\
\hline Calluna & 4 & 0 & 4 & 0 & 0 & 0 & 0 & 0 & 4 \\
\hline Ericaceae & 23 & 83 & 39 & 41 & 17 & 31 & 77 & 27 & 27 \\
\hline Chamaerops & 63 & 11 & 21 & 63 & 23 & 59 & 27 & 0 & 180 \\
\hline Myrtus & 0 & 0 & 3 & 0 & 0 & 4 & 0 & 0 & 0 \\
\hline Pistacia L & 0 & 0 & 25 & 2 & 3 & 25 & 0 & 0 & 0 \\
\hline Tamarix & 0 & 0 & 11 & 39 & 50 & 27 & 16 & 29 & 25 \\
\hline Limonium & 0 & 0 & 0 & 0 & 0 & 0 & 0 & 61 & 59 \\
\hline Cistaceae & 24 & 24 & 37 & 21 & 0 & 4 & 29 & 20 & 13 \\
\hline Nerium & 0 & 0 & 31 & 29 & 23 & 3 & 7 & 3 & 7 \\
\hline Rosaceae & 21 & 19 & 64 & 19 & 41 & 45 & 55 & 13 & 2 \\
\hline Apiaceae & 27 & 29 & 51 & 43 & 61 & 69 & 81 & 49 & 57 \\
\hline Artemisia & 12 & 4 & 0 & 0 & 0 & 4 & 15 & 0 & 0 \\
\hline Asteraceae-l (liguliflorae) & 256 & 281 & 143 & 123 & 279 & 188 & 311 & 215 & 321 \\
\hline Asteraceae-t (tubuliflorae) & 25 & 101 & 33 & 42 & 161 & 177 & 193 & 168 & 119 \\
\hline Boraginaceae & 23 & 50 & 23 & 67 & 27 & 89 & 115 & 89 & 33 \\
\hline Brassicaceae & 0 & 45 & 13 & 0 & 8 & 27 & 8 & 23 & 23 \\
\hline Asphodelus & 39 & 13 & 8 & 20 & 7 & 12 & 3 & 0 & 8 \\
\hline Ceratocapn & 0 & 0 & 0 & 16 & 0 & 0 & 0 & 0 & 0 \\
\hline Caryophyllaceae & 7 & 11 & 12 & 14 & 3 & 7 & 19 & 17 & 24 \\
\hline Papaveraceae & 0 & 0 & 0 & 3 & 0 & 0 & 21 & 41 & 9 \\
\hline Crassulaceae & 0 & 0 & 0 & 0 & 0 & 0 & 0 & 0 & 0 \\
\hline Chenopodiaceae & 4 & 0 & 3 & 4 & 8 & 13 & 12 & 15 & 0 \\
\hline Ephedraceae & 9 & 12 & 21 & 0 & 3 & 12 & 0 & 0 & 17 \\
\hline Fabaceae & 95 & 182 & 161 & 81 & 12 & 99 & 123 & 35 & 91 \\
\hline Fumariaceae & 0 & 0 & 0 & 33 & 0 & 25 & 0 & 24 & 0 \\
\hline Geraniaceae & 3 & 0 & 11 & 0 & 0 & 0 & 0 & 3 & 8 \\
\hline Dipsacaceae & 4 & 3 & 3 & 12 & 0 & 11 & 11 & 0 & 2 \\
\hline Euphorbiaceae & 0 & 0 & 0 & 0 & 0 & 0 & 4 & 0 & \\
\hline Lamiaceae & 21 & 21 & 13 & 3 & 9 & 0 & 37 & 0 & 15 \\
\hline Liliaceae & 35 & 0 & 0 & 4 & 0 & 0 & 0 & 0 & 0 \\
\hline Palmaceae & 0 & 0 & 0 & 0 & 0 & 0 & 0 & 0 & 0 \\
\hline Plantago & 8 & 53 & 0 & 0 & 0 & 0 & 8 & 4 & 0 \\
\hline Poaceae & 13 & 0 & 0 & 4 & 0 & 19 & 7 & 0 & 0 \\
\hline Malvaceae & 3 & 0 & 0 & 0 & 0 & 0 & 3 & 0 & 0 \\
\hline Narcissus & 65 & 29 & 8 & 0 & 0 & 0 & 0 & 0 & 0 \\
\hline
\end{tabular}


Table 2 (continued)

\begin{tabular}{|c|c|c|c|c|c|c|c|c|c|}
\hline \multirow{2}{*}{$\begin{array}{l}\text { Depth }(\mathrm{cm}) \\
\text { Sample }\end{array}$} & \multicolumn{5}{|c|}{ Stratum II } & \multicolumn{4}{|c|}{ Stratum I } \\
\hline & $\begin{array}{l}5.0 \\
\text { Cbn-5 }\end{array}$ & $\begin{array}{l}12.0 \\
\text { Cbn-12 }\end{array}$ & $\begin{array}{l}18.0 \\
\text { Cbn-18 }\end{array}$ & $\begin{array}{l}24.0 \\
\text { Cbn-24 }\end{array}$ & $\begin{array}{l}30.0 \\
\text { Cbn-30 }\end{array}$ & $\begin{array}{l}32.0 \\
\text { Cbn-32 }\end{array}$ & $\begin{array}{l}36.0 \\
\text { Cbn-36 }\end{array}$ & $\begin{array}{l}40.0 \\
\text { Cbn-40 }\end{array}$ & $\begin{array}{l}47.0 \\
\text { Cbn-47 }\end{array}$ \\
\hline Polygonaceae & 22 & 17 & 25 & 13 & 0 & 9 & 7 & 17 & 0 \\
\hline Rhamnaceae & 0 & 0 & 17 & 12 & 12 & 5 & 17 & 8 & 0 \\
\hline Rumex & 13 & 15 & 0 & 0 & 0 & 11 & 13 & 5 & 4 \\
\hline Rubiaceae & 7 & 9 & 12 & 7 & 4 & 0 & 0 & 0 & 0 \\
\hline Sanguisorba minor & 0 & 0 & 0 & 0 & 0 & 0 & 0 & 4 & 0 \\
\hline Sedum & 0 & 0 & 4 & 0 & 0 & 0 & 0 & 0 & 6 \\
\hline Solanaceae & 0 & 4 & 0 & 4 & 0 & 4 & 0 & 3 & 0 \\
\hline Polypodium & 0 & 0 & 121 & 85 & 29 & 60 & 45 & 4 & 17 \\
\hline Violaceae & 0 & 0 & 0 & 0 & 0 & 8 & 0 & 0 & 0 \\
\hline Cyperaceae & 8 & 3 & 0 & 7 & 3 & 0 & 8 & 0 & 0 \\
\hline Polygonum & 3 & 33 & 19 & 15 & 0 & 27 & 19 & 3 & 8 \\
\hline Drosera & 0 & 0 & 3 & 0 & 0 & 0 & 0 & 0 & 0 \\
\hline Junaceae & 20 & 19 & 16 & 0 & 0 & 0 & 0 & 0 & 0 \\
\hline Myriophyllum & 13 & 0 & 0 & 0 & 0 & 0 & 4 & 0 & 0 \\
\hline Nymphaceae & 0 & 0 & 0 & 2 & 0 & 0 & 0 & 0 & 0 \\
\hline Ranunculaceae & 12 & 0 & 0 & 0 & 0 & 0 & 0 & 0 & 0 \\
\hline Typha monada & 37 & 45 & 4 & 27 & 33 & 35 & 19 & 25 & 37 \\
\hline Typha tetrada & 0 & 0 & 0 & 0 & 0 & 0 & 0 & 3 & 0 \\
\hline Esporas monoletas & 25 & 47 & 53 & 51 & 7 & 21 & 9 & 4 & 27 \\
\hline Esporas triletas & 17 & 35 & 27 & 9 & 13 & 13 & 0 & 0 & 0 \\
\hline Concentricistes & 9 & 17 & 41 & 13 & 5 & & 5 & 5 & 0 \\
\hline Total & 1,038 & 1,301 & 1,162 & 1,003 & 896 & 1,213 & 1,364 & 980 & 1,201 \\
\hline
\end{tabular}

(willow), and Ceratonia silique (caron tree), were used for firewood. The environment favored a wide range of hunting, fishing, shellfish gathering, and pastoral activities, as indicated by the faunal remains found in the cave (discussed below). The environmental conditions were not favorable to the development of agricultural practices, for which there is no evidence in the archaeological record. However, some evidence for agricultural activities were found in the Neolithic levels in the nearby site of Caf That el-Gar, dated to 7510-7240 cal. BP (Ballouche and Marinval 2003; Morales et al. 2016).

Topographical and edaphological factors, including the abundance of underground water sources (aquifers), favored the growth of substantial vegetal biomass that was used as fuel by the Neolithic populations in Benzú Cave (Table 3). The following species were used mainly as fuel in the domestic hearths: Quercus ilex-coccifera, Quercus canariensis, Juniperus phoenicea spp., Juniperus oxycedrus spp., Ceratonia siliqua, Olea, Fraxinus angustifolia, Populus alba, Populus nigra, and Salix pedicellata, as well as Laurus nobilis, Arbutus unedo, Chamaerops humilis, and Fabaceae spp.
Evidence collected elsewhere, on the southern shore of the Strait of Gibraltar, suggests similar ecological and economic conditions (Uzquiano and Arnanz 2002; Uzquiano 2008). It may be argued that the open landscapes which resulted from the 8.2-ka climatic eventsudden global decrease in temperature, which lasted between two and four centuries - led to the emergence of a wide variety of shrub species suitable for supporting human groups such as the one documented in Benzú Cave (Mercuri et al. 2011; Fig. 5).

\section{Terrestrial Fauna}

All identified bone remains constitute the number of identified remains (NID), while nonidentified fauna are grouped under the category nonidentified (NI). The determination of the minimum number of individuals (MNI) was carried out according to two methodologies, following Clason's (1972) criteria. For the calculation of the MNI, we also took into account epiphysis fusion, sex, and teeth wear and replacement. We estimated age from the dentition (age of growth, presence of milk 


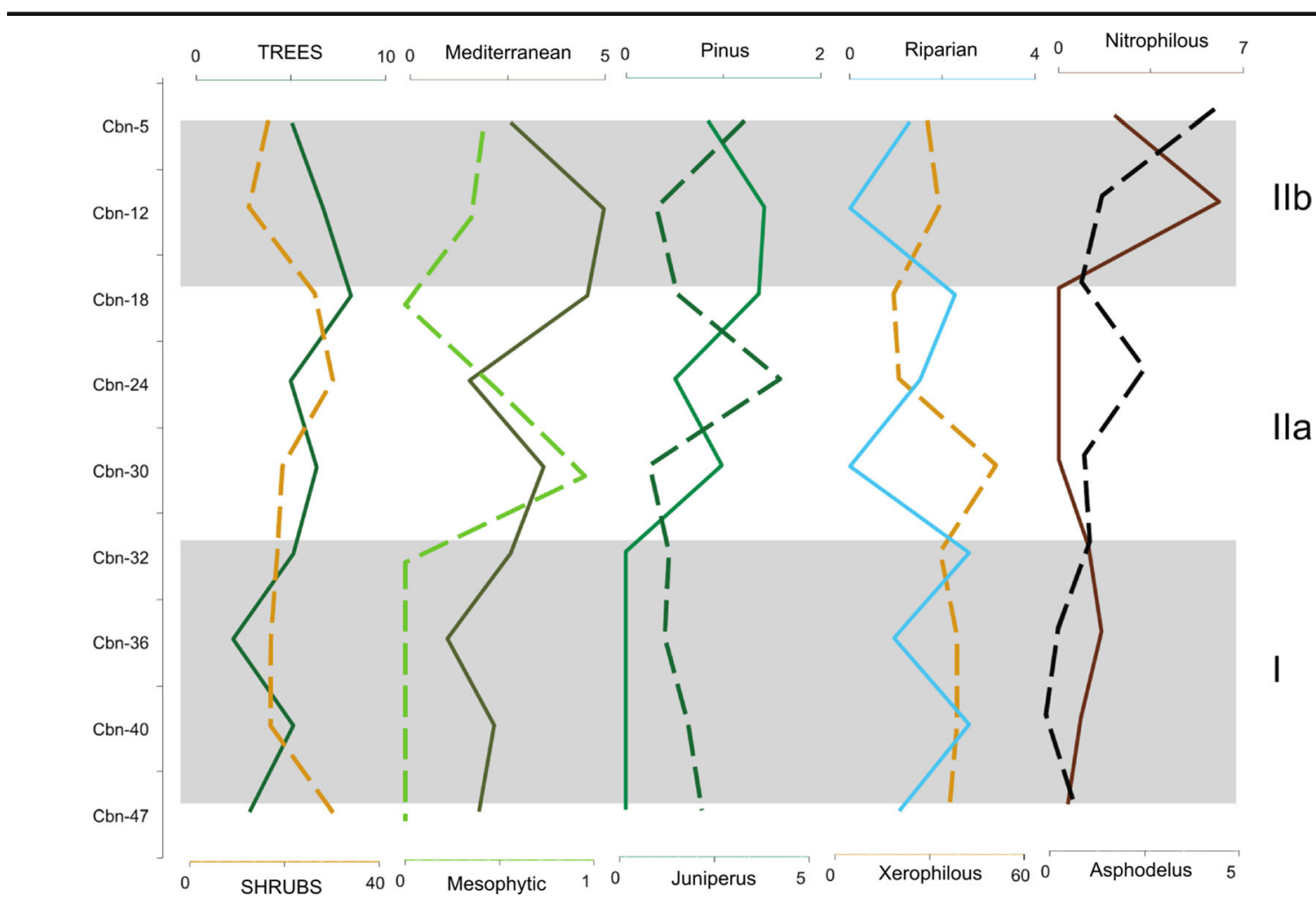

Fig. 4 Most relevant pollen taxa and groups in Benzú

teeth, and wear of adult teeth) and long bone epiphysis. Sex estimates were based on the following bones: pelvis bone for ruminant species; the bone core of horns for domestic sheep, goats, and cattle; and finally, the canine teeth for suidae. Concerning cranial and postcranial measurements, we have followed Driesch's (1976) criteria.

Fauna analysis revealed the predominance of ruminant species (gazelles, Barbary sheep, wild boar, cows, and rhinoceros) and lagomorpha (rabbits, hares) over carnivores (hyenas, jackals, genets, Egyptian mongooses) and rodents (e.g., porcupines) (Tables 4, 5, 6, and 7; Fig. 6). However, these carnivores and rodents appear to be responsible for the accumulation of some of the bones found inside the cave, as well as for the tooth marks on the bones. Most of the animal bones, therefore, appear to postdate the Neolithic period. The fauna assemblage is highly fragmented and presents multiple tooth marks. Some bones have burnt traces, which suggests human action but this can be related to hunting practices, as indicated by the functional analysis of the associated lithic technology (discussed below). The tooth marks suggest that the high degree of fragmentation of the bone remains was mainly due to the activity of porcupines (Dart 1958). Although these animals are herbivores, they are known to gnaw at old bones to obtain calcium. In many of the bones under analysis, these marks have blurred possible human-made cutmarks.

Most of the faunal remains came from wild species, some of which remain abundant in the region today, such as the porcupine. It is unlikely that any of the bone remains belong to a domestic species. Therefore, the animal bone evidence is predominantly related to the occupation of the cave by carnivore and rodent species, rather than the periods of human occupation. Interestingly, the human bones deposited in the cave were spared the attention of the porcupines, as shown by the absence of porcupine tooth marks.

\section{Birds}

A significant proportion of the bones found in the cave correspond to small animals, especially birds (Table 8). All the bird species identified are still present in the region (Hollom et al. 1988; Jiménez and Navarrete 2001). Some of these species, such as the dove, crag martin, blue rock thrush, and western jackdaw, inhabit 
Table 3 Anthracological data, Benzú Cave

\begin{tabular}{|c|c|c|c|c|}
\hline \multicolumn{5}{|l|}{ Benzú Cave (Ceuta) } \\
\hline \multirow{3}{*}{$\begin{array}{l}\text { Chronology } \\
\text { Strata } \\
\text { Taxa }\end{array}$} & \multicolumn{4}{|c|}{ Neolithic } \\
\hline & \multicolumn{2}{|c|}{ ST-II } & \multicolumn{2}{|c|}{ ST-I } \\
\hline & $N$ & $\%$ & $N$ & $\%$ \\
\hline Juniperus phoenicea ssp. turbinata & 4 & 1.05 & & \\
\hline Quercus canariensis & 8 & 2.11 & 1 & 1.72 \\
\hline Quercus t. coccifera & 28 & 7.38 & 6 & 10.34 \\
\hline Quercus suber & 14 & 3.69 & 7 & 12.06 \\
\hline Quercus sp. & 4 & 1.05 & & \\
\hline Salix-Populus & 3 & 0.79 & 2 & 3.44 \\
\hline Fraxinus angustifolia & 18 & 4.74 & 4 & 6.89 \\
\hline Olea europaea & 4 & 1.05 & 1 & 1.72 \\
\hline Ceratonia siliqua & 13 & 3.43 & 1 & 1.72 \\
\hline Arbutus unedo & 55 & 14.51 & 7 & 12.06 \\
\hline Rhamnus alaternus & 4 & 1.05 & & \\
\hline Erica arborea & 4 & 1.05 & & \\
\hline Erica $\mathrm{sp}$ & 25 & 6.59 & 1 & 1.72 \\
\hline Pistacia lentiscus & 9 & 2.37 & & \\
\hline Laurus nobilis & 3 & 0.79 & & \\
\hline t. Teline linifolia & 9 & 2.37 & & \\
\hline t. Teline monspessulana & 2 & 0.52 & & \\
\hline $\begin{array}{l}\text { Teline monspessulana/Calicotome } \\
\quad \text { spinosa }\end{array}$ & 3 & 0.79 & & \\
\hline Calicotome villosa & 8 & 2.11 & & \\
\hline Fabaceae & 83 & 21.89 & 14 & 24.13 \\
\hline Phillyrea sp. & 2 & 0.52 & & \\
\hline Cistus ladanifer & 1 & 0.26 & & \\
\hline Cistus sp. & 2 & 0.52 & & \\
\hline Chamaerops humilis & 13 & 3.43 & 5 & 8.62 \\
\hline Viscum album & 6 & 1.58 & 2 & 3.44 \\
\hline Indeterminables & 54 & 14.24 & 7 & 12.06 \\
\hline Total & 379 & & 58 & \\
\hline
\end{tabular}

or frequent rock cavities so their remains may not necessarily have been brought to the cave by other animals. Other birds, such as the partridge, the remains of which are very abundant, must have been brought in by predators. The species of European honey buzzard, puffin, and northern wheatear are, however, not currently found in the region, and the evidence suggests that neither was the ecosystem amenable to the permanent residence of these species during the Neolithic period. The birds whose habitat would have been consistent with the Neolithic environmental conditions in the region include partridges $(45.65 \%$ of the birds and $23.08 \%$ of the total fauna) and robins ( $2.17 \%$ of the birds and $1.1 \%$ of the entire fauna) who live in bushy areas. Others are Sardinian warblers - a typically Mediterranean species that inhabit shrub and forest; sparrows, which live in open forests; hoopoes which favor open forest conditions but show a preference for more open areas; and quails and corn buntings which live in open areas but prefer tall herbaceous plants and shrubs. The bird species present in the cave suggest a heterogeneous environment-forested areas, shrubs, and open spaces.

\section{Marine Fauna}

The malacofauna record attests to the presence of a considerable variety of species most of which were used for food (Fig. 7). These include Ostrea sp., Mytilus sp., Chlamys sp., Panopea glycimeris, and marine gastropods-including Patella vulgata, Patella ferruginea, and Siphonaria pectinata, as well as the freshwater mollusk and Melanopsis sp. The catchment area of the malacofauna record was very homogeneous. Most of the species live in rocky intertidal areas and are thus easy to gather during low tides (Cantillo 2012; Cantillo et al. 2010, 2014; Cantillo and Soriguer 2011; Ramos and Cantillo 2009; Soriguer et al. 2006). Many of these specimens must have been a food source. However, some were also used for personal adornments during the Bronze Age as attested by anthropic perforations.

Fourteen shells were selected for use-wear analysis based on two criteria: (1) morphology of the taxa and their potential use as tools and (2) the state of preservation of the shells. The samples were examined under various microscopic lenses (augmentation between $\times 10$ and $\times 200$ ) to document their physical characteristics and use-alteration patterns (Cuenca-Solana 2013, 2015; Cuenca-Solana et al. 2013, 2015, 2016, 2017). Possible traces of use were documented on the edge of one fragment of Patella sp., while a whole shell of Patella sp. shows evidence of use. The analysis of use-wear traces and their comparison using various computergenerated simulations suggest that this fragment was used for a short period because the shell broke and that this explains the absence of use-wear traces (CuencaSolana 2013; Cuenca-Solana et al. 2015).

The good preservation of this sample-CB-03-[CXVIII-XIX]-[4]-(1)—provided insights regarding the use of shell as a tool (Fig. $8, \times 10$ ). At the apical 
Fig. 5 Histogram illustrating the anthracological record from Benzú

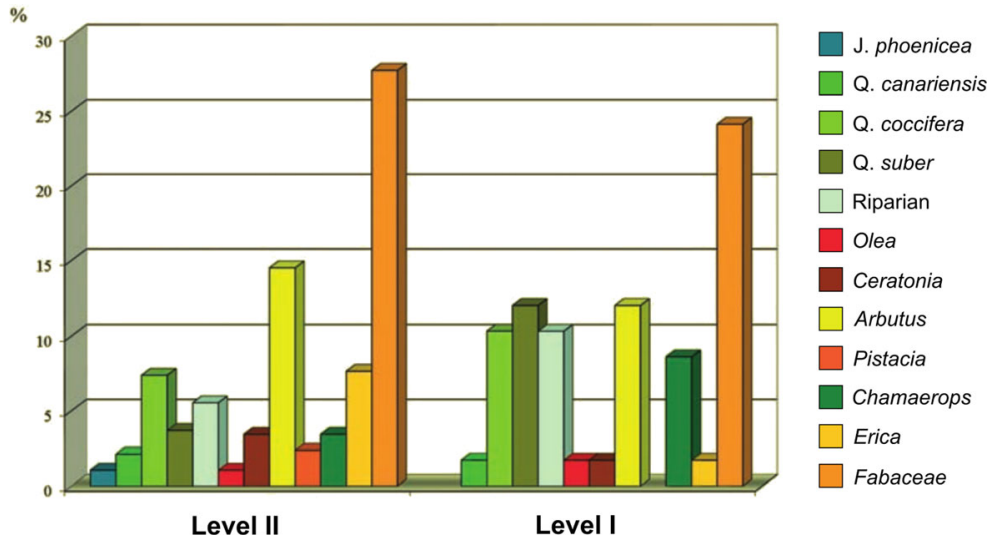

end is a human-made perforation. The irregular contour of the perforation and the denting of its inner face indicate that the perforation was effected by percussion and without previous preparation. Although the perforation is partially fractured, probably as a consequence of taphonomic processes, traces on the area which is better preserved suggest that the shell was suspended. Abrasion and polish marks upon the natural relief of the shell around the perforation are indicative of repeated rubbing by a cord (bottom right in Fig. $8, \times 10$ ). Also, the edge of the perforation presents a small stain of ochre that is not visible to the naked eye (bottom left in Fig. 8, ×10). From the functional point of view, the analysis confirmed that the edge of this shell was used to effect transversal actions upon a mineral object (top left in Fig. 8, ×100). Experimental work indicates that the shell was used for pottery processing (Cuenca-Solana 2013; Cuenca-Solana et al. 2015), probably molding and smoothing the clay during the initial or middle stages of pot making when the clay was still wet. As such, it can be argued that the shell was part of the ceramic production toolkit (Clemente-Conte et al. 2016). The degree of wear on the active area of the shell shows that it was used for this purpose in a sustained manner. In addition, the wear patterns found around the perforation allow us to infer that the shell was carried around suspended by a cord.

Table 4 Stratum I. Anatomical breakdown of bones by identified species

\begin{tabular}{|c|c|c|c|c|c|c|c|c|c|c|}
\hline & Bovid & $\begin{array}{l}\text { Barbary } \\
\text { sheep }\end{array}$ & Boar & Gazelle & $\begin{array}{l}\text { Gazelle/Barbary } \\
\text { sheep }\end{array}$ & Hyena & $\begin{array}{l}\text { Egyptian } \\
\text { mongoose }\end{array}$ & Carnivore & Rabbit & Hare \\
\hline Upper teeth & & & & 1 & & & & & & \\
\hline Lower teeth & 2 & & 2 & 3 & & & & 1 & & \\
\hline Teeth & 1 & & & 66 & 75 & & & & & \\
\hline Humerus & & & & & & & & & 1 & \\
\hline Femur & & & & & & & & & 3 & 1 \\
\hline Tibia & & & & & & & & & 1 & 1 \\
\hline Calcaneus & & 1 & & & & & 1 & & 1 & \\
\hline Talus bone & & & & & & & & & 3 & \\
\hline Tarsus & 1 & & & & & & & & 1 & \\
\hline 1st phalanx & & & 1 & & & & & & 1 & \\
\hline 2nd phalanx & & & 1 & & & & & & & \\
\hline 3rd phalanx & & & & 1 & & & & & & \\
\hline $\begin{array}{l}\text { Metapodial } \\
\text { bones }\end{array}$ & & & & 3 & & 1 & & & 2 & \\
\hline Total & 4 & 1 & 4 & 74 & 75 & 1 & 1 & 1 & 13 & 2 \\
\hline
\end{tabular}


Table 5 Stratum II. Anatomical breakdown of bones by identified species

\begin{tabular}{|c|c|c|c|c|c|c|c|c|c|c|c|c|c|}
\hline & Rhino & Bovid & $\begin{array}{l}\text { Barbary } \\
\text { sheep }\end{array}$ & Boar & Gazelle & $\begin{array}{l}\text { Gazelle/ } \\
\text { Barbary } \\
\text { sheep }\end{array}$ & Hyena & Genet & Canidae & Carnivore & Porcupine & Rabbit & Hare \\
\hline Viscerocranium & & & & 1 & & 1 & & & & & & 1 & \\
\hline Upper teeth & & 2 & 5 & & 4 & 2 & & & 1 & & 7 & & \\
\hline Mandible & & & & & 3 & & & & 1 & 2 & 1 & 6 & \\
\hline Lower teeth & 1 & 6 & 1 & 11 & 10 & 1 & 1 & & & 1 & 7 & & \\
\hline Teeth & & 1 & & 6 & 96 & 712 & & & & & 3 & & \\
\hline Atlas & & & & & & & & & & & & 1 & \\
\hline Vertebrae & & & & & & & & & & & & 6 & \\
\hline Ribs & & & & & & & & & & & & 2 & \\
\hline Scapula & & & & & & & & & & & & 2 & 1 \\
\hline Humerus & & & & 2 & & & & & & & & 3 & 1 \\
\hline Ulna & & & & & 1 & & & & & & 2 & 3 & \\
\hline Radius & & & & & & & & & & & 1 & 1 & 1 \\
\hline Carpal bone & & & 1 & & 2 & 2 & & & & & & & \\
\hline Metacarpal bone & & & 1 & & 2 & & 1 & & & & 1 & & \\
\hline Pelvis & & & & & & & & & & & & & 1 \\
\hline Femur & & 1 & 1 & & 1 & & & & & & & & 1 \\
\hline Tibia & & & & & & & & 1 & & & 1 & 4 & \\
\hline Calcaneus & & & 1 & & 1 & & & & & & & 3 & \\
\hline Talus bone & & & & & 2 & 1 & & & & & & 4 & 1 \\
\hline Tarsus & & & 1 & & 1 & & & & & & & & \\
\hline Metatarsus & & & & & & & & & & & 1 & & \\
\hline 1st phalanx & & 1 & 1 & 2 & 4 & 2 & & & & & & 8 & 1 \\
\hline 2nd phalanx & & & 4 & 3 & 5 & 1 & 2 & & & & & & \\
\hline 3rd phalanx & & & 1 & 1 & 3 & 1 & 2 & & & & & & \\
\hline Metapodial bones & & & & 3 & 4 & 3 & & & & & & 15 & \\
\hline Total & 1 & 11 & 17 & 29 & 139 & 726 & 6 & 1 & 2 & 3 & 24 & 59 & 7 \\
\hline
\end{tabular}

Raw Materials

Petrological and mineralogical studies provide evidence that the sourcing of the raw materials for stone tools involved human mobility and possibly the social networks of the human groups that used the cave. The total number of lithic remains found is 690 . Most of them correspond to a compact quartzite sandstone (435 items-63.04\%), followed by primary flint types, namely flint and radiolarite (249 items - 36.09\%), and a residual amount of quartzite (six items - 0.87\%) (Fig. 9; Table 9). Several siliceous rock sources exist in the vicinity of Benzú, for example, Ued Zarján, Hafa ed Dohor, Hafa Queddana, and Yebel Dersa. In Yebel Musa, which is very close to Benzú, purplish-red radiolarite (associated with nodule-rich
Toarcian-Aalenian limestone) and Dogger-Malm green radiolarite can be attested (Chamorro and Nieto 1989; Chamorro 2004; Domínguez-Bella 2004). The radiolarite (reddish and green) was sourced from the Yebel Musa formations, while the sandstones present the same features as those found in the Beni Yunes flysches, less than $1 \mathrm{~km}$ away from the cave (Domínguez-Bella et al. 2006). There is also evidence that the Neolithic people reused the tools of Middle Paleolithic mode 3 lithic technology.

\section{Lithic Industry}

Stone tools are the most common type of archaeological artifacts in the cave. The 690 lithic tools identified included 29 cores $(5.70 \%), 314$ flakes and blades 
Table 6 Stratum I. Number of identified remains (NIR) and minimum number of individuals (MNI) of identified animal species

\begin{tabular}{lllll}
\hline & NIR & $\%$ & MNI & $\%$ \\
\hline Bovid & 4 & 2.27 & 1 & 3.85 \\
Barbary sheep & 1 & 0.57 & 1 & 3.85 \\
Boar & 4 & 2.27 & 1 & 3.85 \\
Gazelle & 74 & 42.04 & 7 & 26.91 \\
Gazelle or Barbary sheep & 75 & 42.61 & 8 & 30.76 \\
Hyena & 1 & 0.57 & 1 & 3.85 \\
Egyptian mongoose & 1 & 0.57 & 1 & 3.85 \\
Carnivore & 1 & 0.57 & 1 & 3.85 \\
Rabbit & 13 & 7.39 & 4 & 15.38 \\
Hare & 2 & 1.14 & 1 & 3.85 \\
Identified & 176 & 100 & 26 & 100 \\
Not identified & 635 & & & \\
Total & 811 & & & \\
\hline & & & & \\
\hline
\end{tabular}

(57.32\%), and 268 remains of debitage (26.04\%). The flakes and blades were used to produce 79 retouched tools $(10.94 \%)$. The flake-blade to core ratio is $12: 1$, which indicates that the cores were thoroughly used (Vijande 2010). The high proportion of debitage remains suggests that knapping took place inside the cave.

Table 7 Stratum II. Number of identified remains (NIR) and minimum number of individuals (MNI) of identified animal species

\begin{tabular}{lllll}
\hline & NIR & $\%$ & MNI & $\%$ \\
\hline Rhino & 1 & 0.10 & 1 & 2.22 \\
Bovid & 11 & 1.07 & 2 & 4.44 \\
Barbary sheep & 17 & 1.66 & 3 & 6.67 \\
Boar & 29 & 2.83 & 3 & 6.67 \\
Gazelle & 139 & 13.56 & 7 & 15.56 \\
Gazelle/Barbary sheep & 726 & 70.83 & 13 & 28.89 \\
Hyena & 6 & 0.59 & 1 & 2.22 \\
Egyptian mongoose & 1 & 0.10 & 1 & 2.22 \\
Canidae & 2 & 0.19 & 1 & 2.22 \\
Carnivore & 3 & 0.29 & 2 & 4.44 \\
Porcupine & 24 & 2.34 & 4 & 8.89 \\
Rabbit & 59 & 5.76 & 5 & 11.12 \\
Hare & 7 & 0.68 & 2 & 4.44 \\
Identified & 1.025 & 100 & 45 & 100 \\
Not identified & 5.028 & & & \\
Total & 6.053 & & & \\
\hline & & & & \\
\hline
\end{tabular}

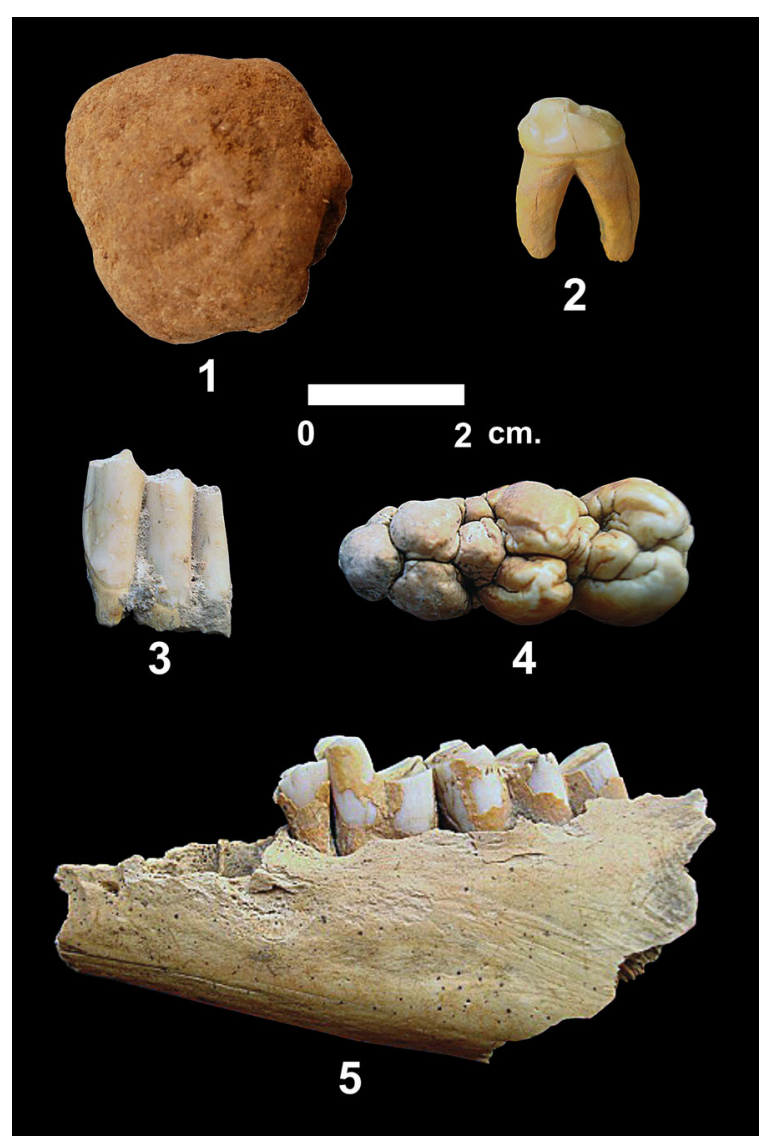

Fig. 6 Faunal remains from Benzú: 1. Hyena coprolite; 2. Hyena lower tooth; 3. Gazelle molar tooth; 4. Wild boar molar tooth; 5. Barbary sheep left hemimandible

Of the 26 cores, 10 are polyhedron-shaped; seven were produced with Levallois technique; two present a percussion surface; two correspond to the initial stages of knapping; and one each has a single percussion surface, prismatic shape, or miscellaneous features. There is also one blade core and a flake.

A total of 289 flakes and 25 blades were identified which amounts to $46.17 \%$ of the total number of worked lithic items. As a result, most retouched products were manufactured using flakes (70.89\%). The typological range is narrow. The geometric types are predominant $(85.71 \%)$, among which rhomboid-shaped types are especially common. The use of microburins is attested only in the single documented trapezoidal-shaped piece (Vijande 2010). A total of 79 retouched products were identified (11.62\%). These included 11 racloirs (this large number is due to the reuse of Mousterian lithic technology found in the cave); two scrapers; one graver; one burin; nine backed edge blades; 27 notches and 
Table 8 Number of identified specimens (NISP) and minimum number of individuals (MNI) of avian remains sorted by taxa and archaeological levels

\begin{tabular}{|c|c|c|c|}
\hline Taxon & Level & NISP & $\mathrm{MNI}$ \\
\hline $\begin{array}{l}\text { Puffinus puffinus/P. yelkouan/ } \\
\quad \text { P. mauretanicus }\end{array}$ & Stratum II & 3 & 3 \\
\hline \multirow[t]{2}{*}{ Alectoris barbara } & Stratum II & 20 & 15 \\
\hline & Stratum I & 1 & 1 \\
\hline Coturnix coturnix & Stratum II & 3 & 3 \\
\hline Pernis apivorus & Stratum II & 2 & 2 \\
\hline Fratercula arctica & Stratum II & 1 & 1 \\
\hline Columba livia/C. oenas & Stratum II & 2 & 2 \\
\hline Upupa epops & Stratum II & 1 & 1 \\
\hline Ptyonoprogne rupestris & Stratum II & 2 & 2 \\
\hline Sylvidae indet. & Stratum II & 1 & 1 \\
\hline Sylvia melanocephala & Stratum II & 1 & 1 \\
\hline Oenanthe oenanthe & Stratum II & 2 & 2 \\
\hline Erithacus rubecula & Stratum I & 1 & 1 \\
\hline Turdus cf. iliacus/T. cf. philomelos & Stratum II & 1 & 1 \\
\hline Monticola saxatilis/M. solitarius & Stratum II & 1 & 1 \\
\hline Emberiza calandra & Stratum II & 2 & 2 \\
\hline Passer cf. hispaniolensis & Stratum II & 1 & 1 \\
\hline Corvus monedula & Stratum II & 1 & 1 \\
\hline Total & & 46 & $41 \mathrm{aa}$ \\
\hline
\end{tabular}

denticulate tools; seven geometrical microliths (six rhomboid- and one trapezoid-shaped); 17 miscellaneous pieces (especially use-retouches); and four abrupt retouches (Fig. 10). Also, scrapers that belong to Mousterian typology were found on the surface of the cave. These were likely collected from the nearby rockshelter of Benzú (situated $5 \mathrm{~m}$ from the cave). This shelter presents seven brecciated levels dated to the Middle Paleolithic (Ramos-Muñoz et al. 2008, 2016). Erosion can affect brecciated levels, bringing these materials to the surface, and allowing the Neolithic inhabitants of the cave to reuse the Paleolithic tools.

Concerning the functional analysis of these tools, the taphonomic processes related to the sedimentary conditions of the cave made it impossible to carry out a microscopic analysis of the lithic surface. Nevertheless, we were able to determine the use of dorsal blades and geometric pieces (e.g., projectile points) based on the impact fractures and the position of the possible remains of resin used to attach these points to a shaft (Fig. 10). Rhomboid-shaped points are characteristic of the region of the Strait of Gibraltar and are found only in North Africa. It is likely that these points were used for hunting wild

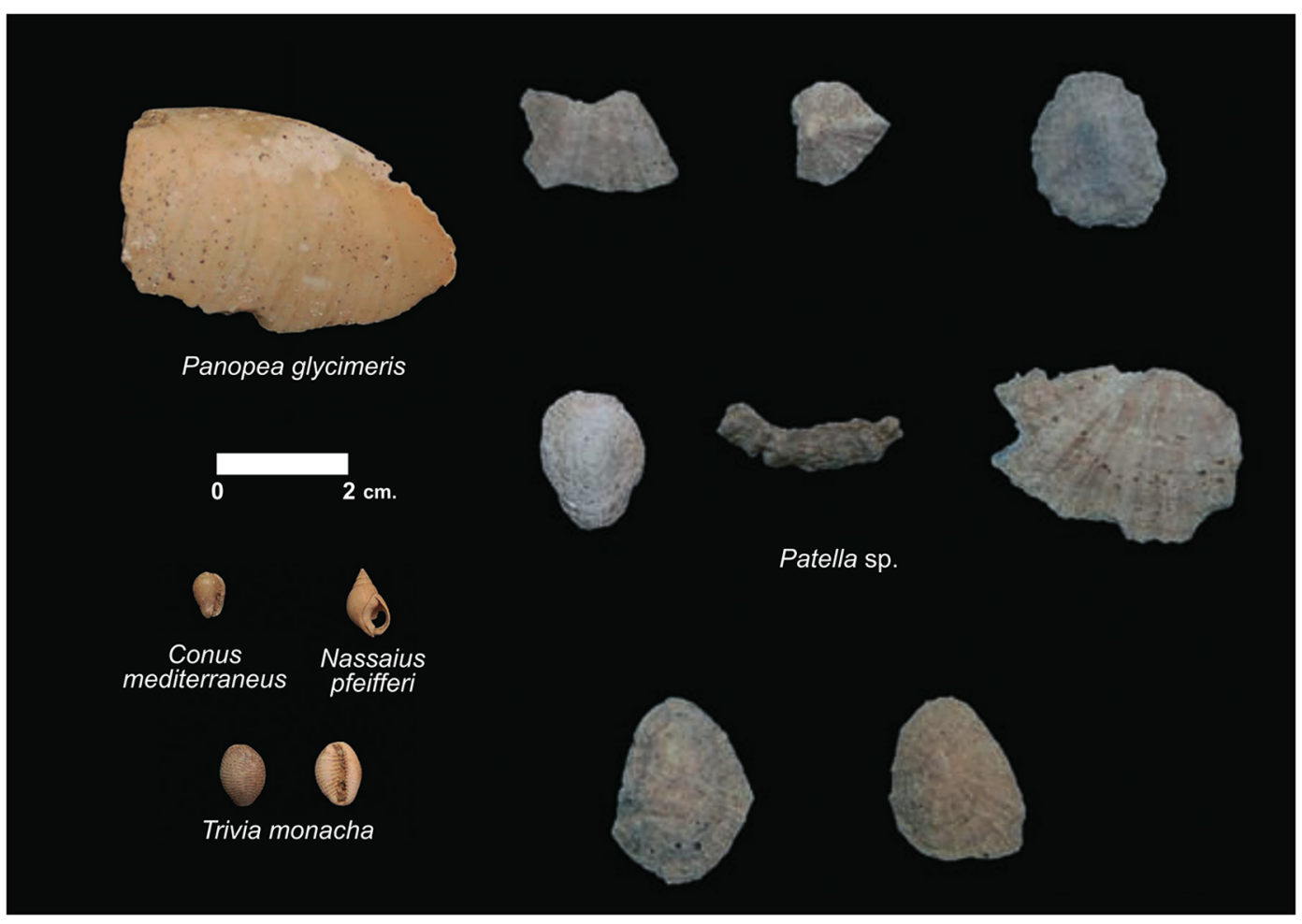

Fig. 7 Malacological record from Benzú 
Fig. 8 Patella sp. CB-03-[CXVIII-XIX]-[4]-(1) shell, from stratum II. This shell was used as a tool in pottery making during the Neolithic. The $\times 100$ image illustrates the use marks left on the shell. The bottom image $(\times 10)$ shows the perforation used to suspend the shell and some ochre remains

Fig. 9 Lithology of stone products found in Benzú. a Compact or silicified sandstone. $\mathbf{b}$ White and red radiolarite. c Green radiolarite. d Black flint
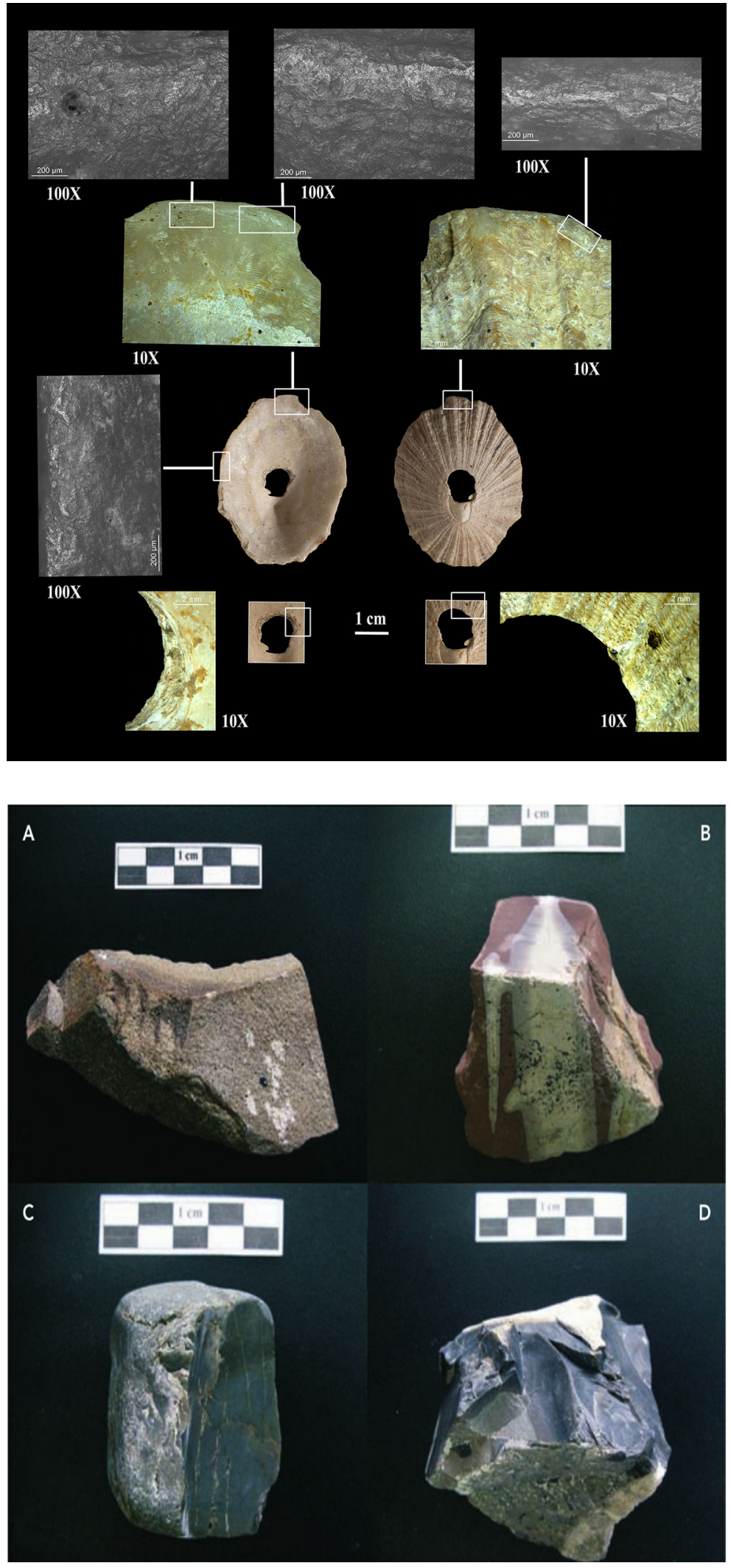
Table 9 Number and percentage of items by raw material and strata

\begin{tabular}{|c|c|c|c|c|c|c|c|}
\hline & Stratum I & $\%$ & Stratum II & $\%$ & Surface & $\%$ & Total $\%$ \\
\hline Quartzite sandstone & 24 & 64.86 & 348 & 61.70 & 61 & 68.54 & 62.75 \\
\hline Flint & 13 & 35.14 & 209 & 37.06 & 28 & 31.46 & 36.23 \\
\hline Quartzite & 0 & 0 & 7 & 1.24 & 0 & & 1.01 \\
\hline
\end{tabular}

game. The absence of harvesting or gathering tools and domesticated fauna, as well as evidence of in situ manufacture of hunting tools, indicates that the site was used as a base for hunting and shellfish gathering (Vijande 2011).

\section{Pottery}

Seventy-one pottery fragments were found in Benzú, seven of which were collected from the surface, while 64 were found in stratigraphic contexts (three
Fig. 10 Retouched products from Benzú. The traces found by the analyses indicate that they were used as projectile points: $\mathbf{a}-\mathbf{h}$, geometrical; $\mathbf{i}-\mathbf{s}$, abatededge flakes and blades; $\mathbf{t}$, burin
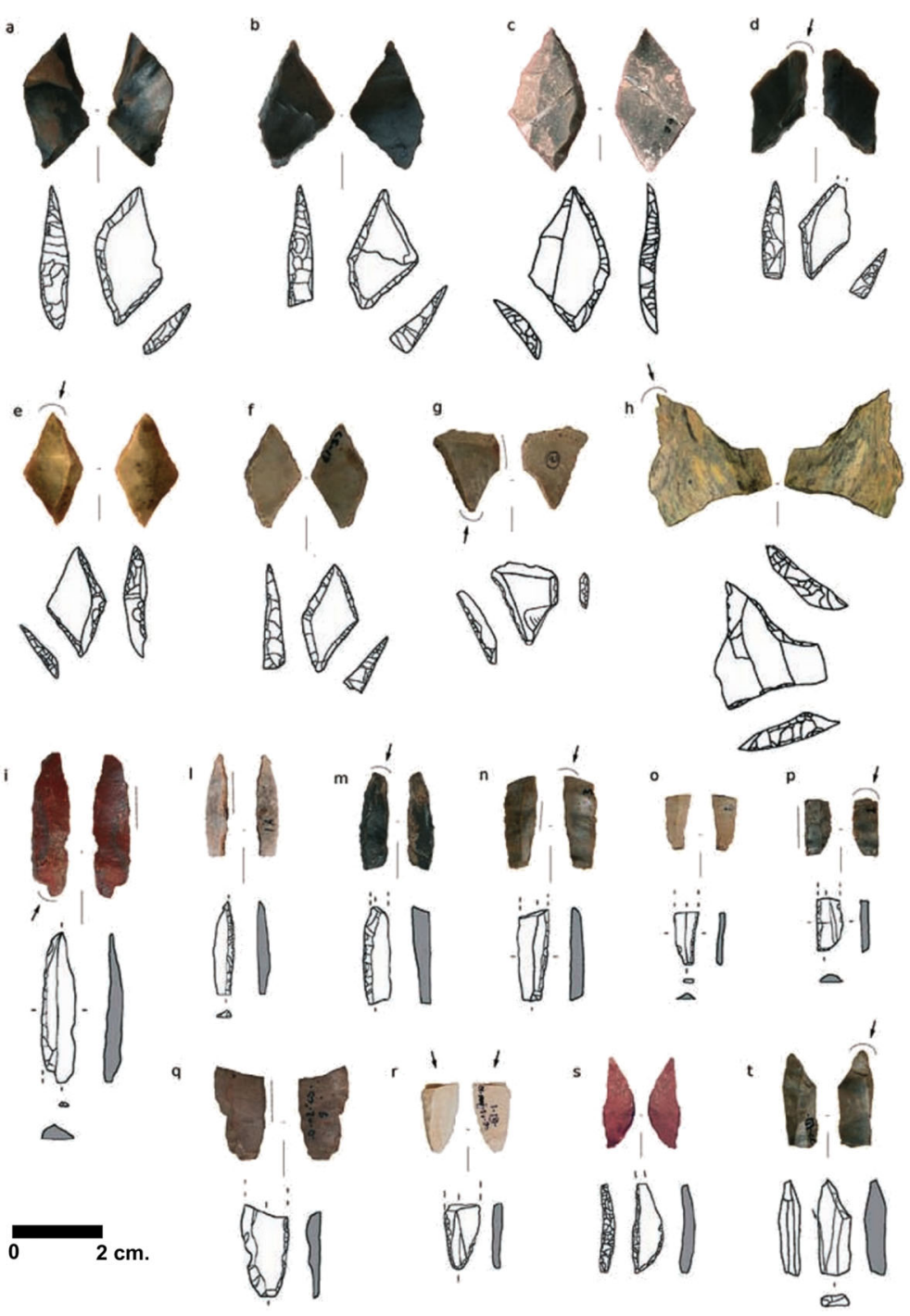
in stratum I and 61 in stratum II). Most of them belong to body fragments (56), and the rest are rims (13) and bases (two). The clay used for the manufacture of these vessels was poorly decanted and included abundant inorganic tempers (essentially quartz and calcite). The vessels are rather crude hand-made shapes, although some of them present burnished surfaces, both in the interior and the exterior. The firing was continuous and even. Several forms were attested, including bowls with incurving rims, pots with vertical wall and rounded lip, hemispherical bowls, semispherical bowls, open bowls, flat-bottomed cups, and conical-bottomed cups (Fig. 11). The forms indicate that these ceramic shapes were used for food processing and consumption.

\section{Human Remains}

The human remains from the excavation are limited to 61 teeth, 21 fingers/toe phalanges, and a fragmentary diaphysis from a tibia. These bone remains were found in stratum II, in squares AXVII-XVIII, -AXVIII-XIX,
AXVIII-XIX, -AXIX-XX, AXIX-XX, and -AXX-XXI (see Fig. 3). The absence of cranial and almost all postcranial remains could suggest that the cave once served as a primary burial place but that the remains were later exhumed and taken to a different location. Some of the individuals' teeth and finger/toe phalanges, due to their small size, were left behind in the process.

In total, the analysis has identified a minimum number of seven individuals, comprised of one juvenile individual and six adolescents/adults. The significant wear of some of the teeth and the presence of arthritis on some finger/toe phalanges indicate that some of these remains belonged to old people. The bones point to a slender body type, as suggested by the small size of the teeth as well as feet and hand phalanxes. Concerning paleobiological traces, the teeth present no caries but substantial layers of plaque. Two molar pieces present evidence for the use of wooden toothpicks (fine parallel microstriations in the interproximal surface of the teeth). Similarly, some front teeth present dental hypoplasia, and the position of this on the tooth crown indicates that this
Fig. 11 Ceramic items from Benzú: 1. Bowl with incurving rim; 2. Cup with vertical walls; 3 . Pot with rounded rim; 4 . Bowl with incurving rim; 5 .

Hemispherical bowl; 6. Open bowl; 7. Semispherical bowl; 8 . Flat-bottomed cup; 9. Conical bottom
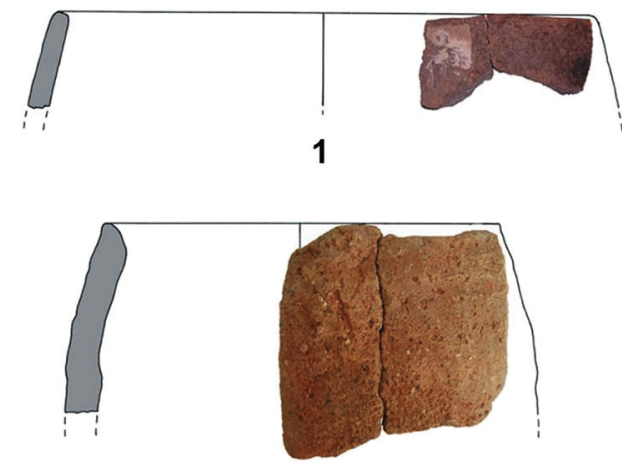

2

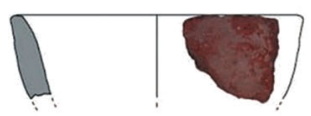

5

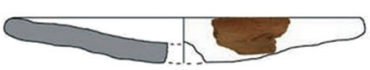

6

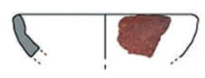

7
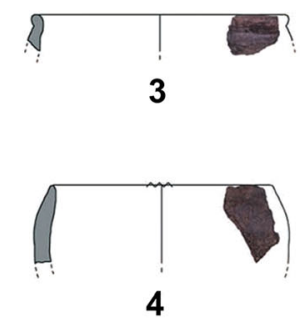

0 $10 \mathrm{~cm}$. 

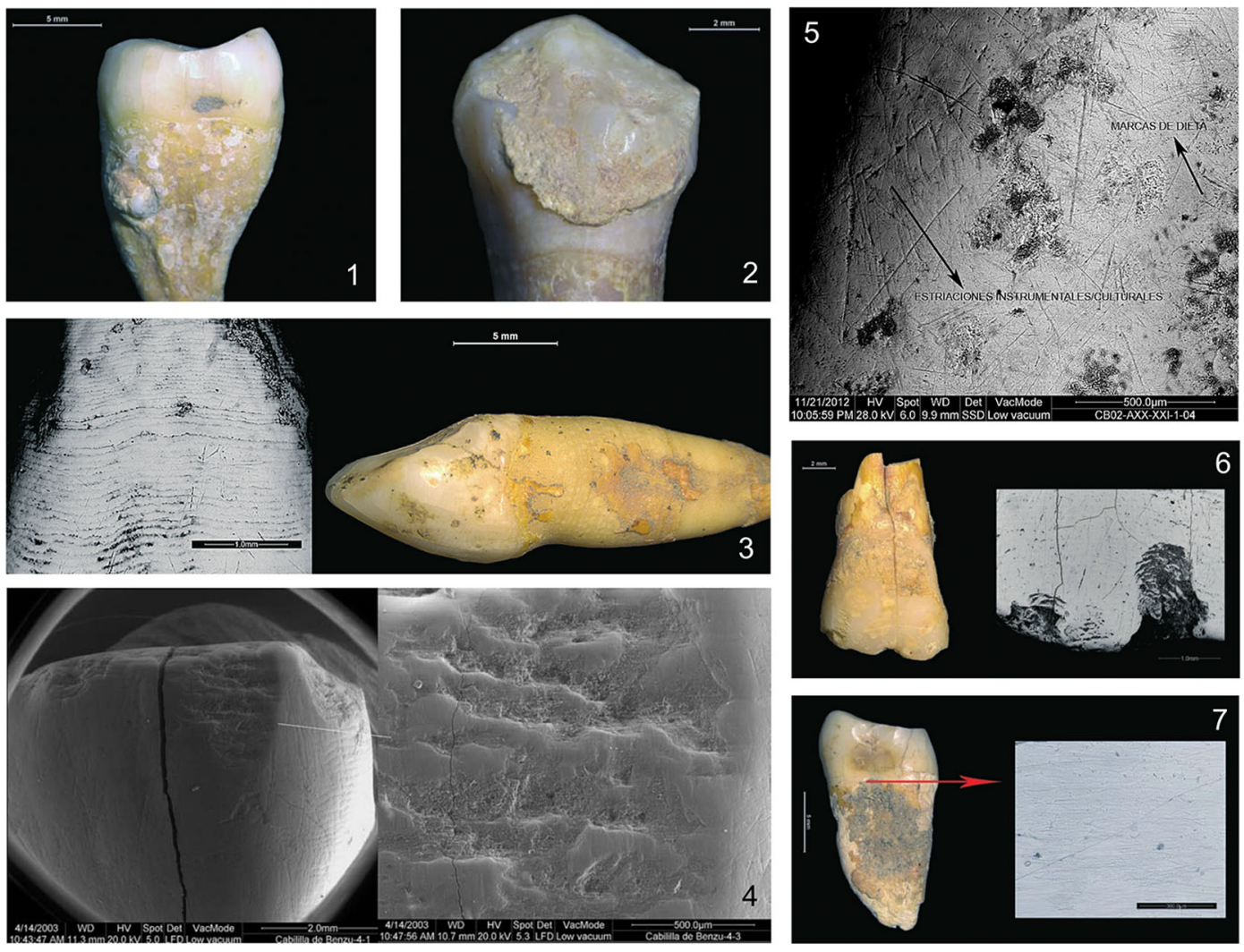

Fig. 12 Human teeth, presenting different features: 1. Enamel pearl in upper molar; 2. Plaque deposit in first right premolar; 3. Pieces with dental hypoplasia; 4. Loss of enamel; 5. Man-made

episode must have taken place when the individuals were between 2.5 and 3.5 years old, which in prehistoric groups is generally related to weaning. Some incisors and canine teeth present cultural striations - the chipping of the tooth enamel on some of the top teeth and also on some molars - resulting from using the teeth for the manipulation of hard objects. Also of note is the identification of "enamel pearl" on an upper molar (Fig. 12).

\section{Personal Adornments}

The personal adornments documented in Benzú include beads and pendants. Pendants are natural items which have not been altered except for perforation, while beads involve a more elaborate process of manufacture. A total of 21 elements of personal adornment were found, including 14 serpentine beads, three shell beads, and four shell pendants (Fig. 13). The high number of serpentine beads is not surprising due to the presence of a nearby $(8 \mathrm{~km})$ source of peridotite and serpentine in Sarchal, Ceuta (Chamorro and Nieto 1989; Domínguez-Bella striations; 6. Chipped enamel; 7. Fine and parallel microstriations caused by the use of toothpicks

et al. 2013). The shell species used as pendants are Patella sp., Nassarius pfeifferi, and Trivia monacha. Three disc-shaped shell beads were also found. Due to postdepositional disturbances, and the fact that the Bronze Age grave was cut into the Neolithic levels, it is difficult to ascertain which of the personal adornment artifacts were associated only with funerary offerings or personal ornaments (e.g., elements of clothing). However, given the concentration of these artifacts (21) in such a small space and that most of the beads were found in the same grids where the human remains were identified, we would propose that the personal adornment artifacts were most likely used in the Bronze Age mortuary rituals.

\section{Discussion and Conclusions}

Despite the small size of the Benzú Cave, the excavations yielded a very diverse range of artifacts, and the spatial and formal analysis of these remains produced interesting results. At least, three diachronic types of 

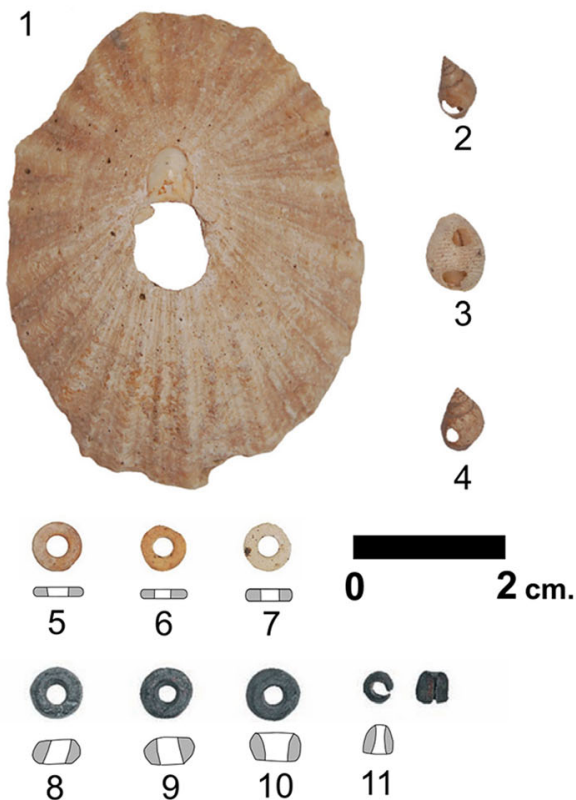

Fig. 13 Personal adornments associated to burial practices (left): 1-4. Shell pendants; 5-7. Shell beads; 8-10. Serpentine beads; 11. Copper bead. Experimental reconstruction of the production of serpentine beads (right): A. Collection of serpentinite and

activity have been attested (see Fig. 3). First, pastoral groups used the cave for shelter by the sixth millennium BCE. The occupation of the cave would have been seasonal rather than permanent. The high number of worked stone remains suggests in situ stone knapping. The presence of gravers and racloirs, as well as pottery shapes used for the processing and consumption of food, also indicates other everyday activities. Given the small size of the cave, its use as an animal pen is unlikely, but Neolithic herding groups in the region may have used it as a temporary shelter as it is being done today. We must also point out the presence of anthracological remains of different species related to herding activities, including Fabaceae, used by herders for kindling, and also demonstrated in other anthracological analyses in the Iberian Peninsula (Uzquiano 1992, 2002; Uzquiano and Zapata 2000); and ash, a foraging plant which in Western European anthracological records appears in association with herding practices (Thiébault 1988; Uzquiano 2000). However, there is no evidence that farmers camped in the cave or that farming activities took place nearby. We have also observed that the ecology of the area is not well suited for agricultural practices.

A survey carried out in 2001 in the area led to the identification of several Neolithic sites, as far as near the town of Benzú (Bernal 2002; Bernal et al. 2003). The

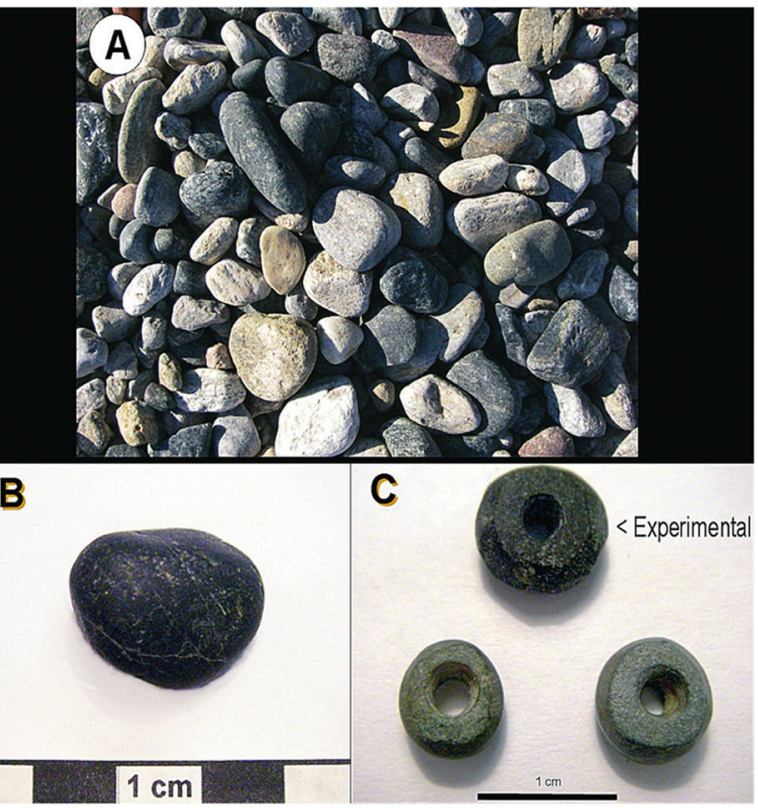

peridotite in El Sarchal beach (Ceuta); B. Serpentinite pebble; C. Serpentinite beads (Neolithic example found in Benzú and reproduction, crafted from a serpentinite pebble by S. Domínguez-Bella in 2006)

survey also detected three isolated Neolithic finds (Casa de Zapatero I, Casa de Zapatero II, and Hacho I) (Bernal et al. 2003). Another survey undertaken in 2011 identified more Neolithic sites, in Altabacal and Cueva de Enrique, along with isolated Neolithic finds (Explanada Alta de Benzú, Fuente de San Francisco). Some of these sites seem to correspond to permanent settlements, more developed agricultural and pastoral activities, and a more complex social structure (Vijande et al. 2011). In addition, the Spanish-Moroccan team working in the neighborhood of Oued Laou and Oued Liane in the Tingitana Peninsula, in the context of the work undertaken between 2008 and 2011 for the production of the archaeological map of northern Morocco, documented no fewer than 48 Neolithic sites. These seem to have been occupied by farmers who relied on the exploitation of fertile soils in the interior (Ramos et al. 2015). These sites include the Marsa rock shelter and the open agricultural settlement of Ghabat Jamâa (Ramos-Muñoz et al. 2018). These finds confirm the intensive occupation of this region during the Neolithic (Ramos and Bernal 2006; Ramos et al. 2003; Vijande et al. 2008; Vijande 2010). As such, Benzú Cave was part of a wider Neolithic landscape along the African shore of the Strait of Gibraltar (see regional syntheses in Cantillo 2012; Vijande 2010, 2011). 
During the second millennium BCE, the Bronze Age period, the cave was used for funerary purposes and became the burial place of at least seven individuals. The human remains (teeth and finger/toe phalanges) and elements of personal adornment (serpentine necklace beads, copper, and shells) found in the cave demonstrate the variety of ritual practices in the region of the Strait of Gibraltar during this period. The use of caves for funerary purpose on the southern shore of the strait had previously been documented only in El Hafa II (Ramos et al. 2011; Raissouni et al. 2015) and nearby, in Bray Cave, Gibraltar (Giles Guzmán et al. 2017). The radiocarbon dates from these two sites are contemporaneous with those of the human remains in Benzú indicating that some of the natural caves were used for funerary contexts during the Early Bronze Age.

Acknowledgments We wish to thank the City Council of Ceuta for funding this research within the framework of its agreement with Universidad de Cádiz, and the project 'La implantación de las especies domésticas en la Europa atlántica: sociedades neolíticas y uso de materias primas líticas en la región del estrecho de Gibraltar', Plan Nacional I+D, MCYT. HAR2008-06477-C03-02. DCS carried out the analyses reported in this work with the support of Programa de Investigación Juan de la Cierva (IJCI-2014-20590), Ministerio de Economía y Competitividad, de España. This research was carried out within the administrative framework of Proyecto de Investigación de I+D HAR2017-87324-P, ‘Análisis de sociedades prehistóricas (del Paleolítico Medio al Neolítico Final) en las dos orillas del Estrecho de Gibraltar. Relaciones y contactos', by Ministerio de Economía, Industria y Competitividad de España.

Funding This study was funded by City Council of Ceuta (65.933/20 [01], 47.849/3 [03], 007086, 77.891/3 [09], 96.478/2 [2010], 0-094/2011, 124.111/3[2011], 23.685/[13]), Plan Nacional I+D, MCYT. (HAR2008-06477-C03-02), Programa de Investigación Juan de la Cierva, Ministerio de Economía y Competitividad, de España (IJCI-2014-20590), and Proyecto de Investigación de I+D (Ministerio de Economía, Industria y Competitividad de España) (HAR2017-87324-P).

\section{Compliance with Ethical Standards}

Conflict of Interest The authors declare that they have no conflict of interest.

\section{References}

Ballouche, A., \& Marinval, P. (2003). Données palynologiques et carpologiques sur la domestication des plantes et l'agriculture dans le Néolithique ancien du Maroc Septentrional (Site de Kaf That El-Ghar). Revue d'Archéométrie, 27, 49-54.
Bernal, D. (2002). La carta arqueológica terrestre de Ceuta. Una apuesta decisiva por el patrimonio municipal. Revista de Arqueología, 253, 46-53.

Bernal, D., Lorenzo, L., Castañeda, V., \& Ramos, J. (2003). La Carta Arqueológica de Ceuta. Historiografía y resultados de la prospección del año 2001. Registro y yacimientos prehistóricos. In J. Ramos, D. Bernal, \& V. Castañeda (Eds.), El Abrigo y la Cueva de Benzú en la Prehistoria de Ceuta (pp. 77-159). Cádiz: Consejería de Educación y Cultura de Ceuta, UNED Ceuta y Servicio de Publicaciones de la Universidad de Cádiz.

Cantillo, J. J. (2012). Análisis arqueomalacológico del Abrigo y Cueva de Benzú (Ceuta). El aprovechamiento de los recursos acuáticos por sociedades prehistóricas en la región histórica del Estrecho de Gibraltar. Ph.D. dissertation. Universidad de Cádiz.

Cantillo, J. J., \& Soriguer, M. (2011). La explotación de los recursos marinos por las sociedades cazadoras-recolectoraspescadoras. In J. Ramos, D. Bernal, A. Cabral, E. Vijande, \& J. J. Cantillo (Eds.), Benzú y los orígenes de Ceuta (pp. 103110). Ceuta: Ciudad Autónoma de Ceuta, Museo de la Basílica Tardorromana de Ceuta y Universidad de Cádiz.

Cantillo, J. J., Ramos, J., Soriguer, M., Pérez, M., Vijande, E., et al. (2010). La explotación de los recursos marinos por sociedades cazadoras-recolectoras-mariscadores y tribales comunitarias en la región histórica del Estrecho de Gibraltar. Férvedes, 6, 105-113.

Cantillo, J. J., Vijande, E., Ramos, J., Zouak, M., \& Soriguer, M. (2014). Análisis arqueomalacológo de la cueva de Gar Cahal en el contexto regional del norte de Marruecos (Península Tingitana). Archaeofauna, 23, 117-132.

Chamorro, S. (2004). Marco geológico del Abrigo y Cueva de Benzú. In J. Ramos, D. Bernal, \& V. Castañeda (Eds.), Investigación interdisciplinar en Humanidades. Excavaciones arqueológicas en el yacimiento de Benzú (Ceuta) (pp. 145-151). Ceuta: XVI Edición de los Cursos de Verano de la Universidad de Granada en Ceuta.

Chamorro, S., \& Nieto, M. (1989). Síntesis geológica de Ceuta. Iltre. Ayuntamiento de Ceuta. Consejería de Cultura. Ceuta: Servicio de Publicaciones.

Clason, A. T. (1972). Some remarks on the use and presentation of archeozoological data. Helenium, 12(2), 140-153.

Clemente-Conte, I., Mazzucco, N., Cuenca-Solana, D., \& Mozota Holgueras, M. (2016). The toolkit for pottery production and repair in prehistory. In O. V. Lozovskaya, A. N. Mazurkevich, \& E. V. Dolbunova (Eds.), Traditions and innovations in the study of earliest pottery: Materials of the international conference (pp. 135-139). St. Petersburg: Russian Academy of Sciences.

Coûteaux, M. (1977). A propos de l'interprétation des analyses polliniques de sediments minéraux principalement archéologiques on le milieu vegetal, les faunes et l'homme. A.F.E.Q. Supplément Bulletin, 47, 259-276.

Cuenca-Solana, D. (2013). Utilización de instrumentos de concha para la realización de actividades productivas en las formaciones económico-sociales de los cazadoresrecolectores-pescadores y primeras sociedades tribales de la fachada atlántica europea. Publican: Servicio de publicaciones de la Universidad de Cantabria.

Cuenca-Solana, D. (2015). The use of shells by hunter-fishergatherers and farmers from the early upper Palaeolithic to 
the Neolithic in the European Atlantic façade: A technological perspective. Journal of Island and Coastal Archaeology, 10(1), 52-75.

Cuenca-Solana, D., Gutiérrez Zugasti, I., González Morales, M. R., Setién, J., Ruiz, E., et al. (2013). Shell technology, rock art and the role of coastal resources in the Upper Palaeolithic. Current Anthropology, 54(3), 370-380.

Cuenca-Solana, D., Dupont, C., \& Hamon, G. (2015). Instrumentos de concha y producción cerámica en los grupos tribales neolíticos de la costa atlántica del oeste de Francia. In I. Gutiérrez-Zugasti, D. Cuenca-Solana, \& M. R. González Morales (Eds.), Actas de la IV Reunión de Arqueomalacología de la Península Ibérica. Publican: Servicio de Publicación de la Universidad de Cantabria.

Cuenca-Solana, D., Gutiérrez Zugasti, I., Ruiz Redondo, A., González Morales, M. R., Setién Marquínez, J., et al. (2016). Painting Altamira Cave? Shell tools for ochreprocessing in the Upper Paleolithic. Journal of Archaeological Science, 74, 135-151.

Cuenca-Solana, D., Gutiérrez-Zugasti, I., \& González Morales, M. R. (2017). Use-wear analysis: Optimal methodology for the study of the shell tools. Quaternary International Part A, 427, 192-200.

Dart, R. A. (1958). Bone tools and porcupine gnawing. American Anthropologist, New Series, 60(4), 715-724.

Daugas, J. P., \& El Idrissi, A. (2008). Neolítico Antiguo de Marruecos en su contexto regional. In J. Ramos, M. Zouak, D. Bernal, \& B. Raissouni (Eds.), Las ocupaciones humanas de la cueva de Caf That el Ghar (Tetuán). Los productos arqueológicos en el contexto del Estrecho de Gibraltar (pp. 63-91). Cádiz: Colección de Monografías del Museo Arqueológico de Tetuán I. Servicio de Publicaciones de la Universidad de Cádiz, Diputación de Cádiz y Dirección Regional de Cultura Tánger-Tetuán.

Daugas, J. P., Raynal, J. P., Ballouche, A., Occhietti, S., Pichet, P., Evin, J., Texier, J. P., \& Debénath, A. (1989). Le Néolithique nordatlantique du Maroc: Premier essai de chronologie par le radiocarbone. Comptes rendus de l'Académie des Sciences de Paris, 308, série II, 681-687.

Daugas, J. P., Raynal, J. P., El Idrissi, A., Ousmoi, M., Fain, et al. (1999). Synthèse radiochronométrique concernant la séquence néolithique au Maroc. $14 \mathrm{C}$ et Archéologie. 3éme Congrès International, Lyon 610 avril 1998, Mémoires de la Société préhistorique française, 26, et supplément de la Revue d'Archéométrie, 349-353.

Daugas, J. P., El Idrissi, A., Balouche, A., Marinval, P., \& Ouchaou, B. (2008). Le Néolithique ancien au Maroc septentrional: Données documentaires, sériation typochronologique et hypothèses génétiques. Bulletin de la Société préhistorique Française, 105(4), 787-812.

Domínguez-Bella, S. (2004). Arqueometría, materias primas minerales, captación, distribución y consumo de recursos líticos en el yacimiento de Benzú. In J. Ramos, D. Bernal, \& V. Castañeda (Eds.), Investigación interdisciplinar en Humanidades. Excavaciones arqueológicas en el yacimiento de Benzú (Ceuta) (pp. 153-159). Ceuta: XVI Edición de los Cursos de Verano de la Universidad de Granada en Ceuta.

Domínguez-Bella, S., Chamorro, S., Ramos, J., \& Bernal, D. (2006). Análisis arqueométrico de la industria lítica y las Materias primas minerales y geología en el entorno del abrigo y la cueva de Benzú. In G. Martínez, A. Morgado, \& J. A.
Afonso (Eds.), Sociedades Prehistóricas, Recursos Abióticos y Territorio (Actas III Reunión de trabajo sobre Aprovisionamiento de Recursos Abióticos en la Prehistoria) (pp. 119-133). Granada: Fundación Ibn al-Jatib de Estudios de Cooperación Cultural, Ayuntamiento de Loja, Artífice y Diputación de Granada.

Domínguez-Bella, S., Vijande, E., \& Ramos, J. (2013). Materias primas de los productos arqueológicos. Segunda parte. La cueva de Benzú. In R. Muñoz, D. Bernal, E. Vijande, \& J. J. Cantillo (Eds.), El abrigo y la cueva de Benzú. Memoria de los trabajos Arqueológicos de una década en Ceuta (20022012) (pp. 607-622). Ciudad Autónoma de Ceuta y Servicio de Publicaciones Universidad de Cádiz.

Driesch, A. von den (1976). A guide to the measurement of animal bones from archaeological sites. Peabody Museum Bulletins, I. Harvard University Cambridge, MA.

Giles Guzmán, F., Giles Pacheco, F., Gutiérrez, J. M., Reinoso, C., Finlayson, C., et al. (2017). Bray, una cueva sepulcral de la Edad del Bronce en el Peñón de Gibraltar. Sagvntvm (P.L.A.V.), 49, 29-42.

Gilman, A. (1975). A later prehistory of Tangier. Morocco American School of Prehistoric Research. Peabody Museum Bulletin 29. Harvard University Cambridge, MA.

Goeury, C., \& de Beaulieu, J. L. (1979). A propos de la concentration du pollen a l'aide de la liquer de Toulet dans les sediments mineraux. Pollen et Spores, XXI(1-2), 239-251.

Hollom, P. A. D., Porter, R. F., Christensen, S., \& Willis, I. (1988). Birds of the Middle East and North Africa. Arrington: Buteo Books.

Howe, B., \& Movius, H. L., Jr. (1947). A Stone Age cave site in Tangier: Preliminary report on the excavations at the Mugharet El 'Aliya, or High Cave, in Tangier. Papers of the Peabody Museum of American Archaeology and Ethnology, Harvard University, 28, 1.

Jiménez, J., \& Navarrete, J. (2001). Estatus y fenología de las aves de Ceuta. Ceuta: Instituto de Estudios Ceutíes.

Koehler, H. (1931). La Grotte d'Achakar au Cap Spartel. Études de Préhistoire Marocaine. I. Bourdeaux: Institut d'Études de Religions de l'Évêché de Rabat (Maroc).

Linstädter, J. (2008). The Epipalaeolithic-Neolithic transition in the Mediterranean region of Northwest Africa. Quartar, 55, 41-62.

Linstädter, J. (2011). The Epipalaeolithic-Neolithic transition in the Eastern Rif Mountains and the Lower Moulouya valley, Morocco. In J. Guibaja \& A. F. Carvalho (Eds.), The last hunter-gatherers and the first farming communities in the south of the Iberian Peninsula and north of Morocco (pp. 89100). Proceedings of the workshop Faro 2, 4.11.2009.

Linstädter, J. (2016). Climate induced mobility and the missing middle Neolithic of Morocco. In M. Reindel, K. Bartl, F. Lüth, \& N. Benecke (Eds.), Palaeoenvironment and the development of early settlements (pp. 63-80). Proceedings of the International Conferences Palaeoenviroment and the development of early societies (Șanliurfa / Turkey, 5-7 October 2012).

Linstädter, J., Aschrafi, M., Ibouhouten, H., Zielhofer, C., Bussmann, J., et al. (2012). Flussarchäologie der Moulouya Hochflutebene, NOMarokko (Vol. 53, pp. 1-84). Madrider Mitteilungen.

Martínez Sánchez, R. M., Vera Rodríguez, J. C., Peña-Chocarro, L., Perez Jorda, G., Bokbot, Y., \& Pardo-Gordo, S. (2018). 
The middle Neolithic of Morocco's North-Western Atlantic strip: New evidence from the El-Khil Caves (Tangier). African Archaeological Review, 35(3), 417-442.

Mercuri, A. M., Sadori, L., \& Uzquiano, P. (2011). Mediterranean and North-African cultural adaptations to mid-Holocene environmental and climatic changes. The Holocene, 21(1), 189-206.

Mikdad, A., Eiwanger, J., Atki, H., Ben-Nçer, A., Bokbot, Y., et al. (2000). Recherches préhistoriques et protohistoriques dans le Rif oriental (Maroc). Rapport préliminaire. Beiträge zur Allgemeinen und Vergleichenden Archäologie, 20, 109-167.

Mikdad, A., Nekkal, F., Nami, M., Zielhofer, C., \& Amani, F. (2012). Recherches sur le peuplement humain et l'evolution paléoenvionnementale durant le Pléistocène et l'Holocène au Moyen Atlas central: Résultats préliminaires. Bulletin d'Archéologie Marocaine, 22, 53-71.

Millán, A., \& Benéitez, P. (2003). Datación absoluta por termoluminiscencia de material cerámico de la Cueva de Benzú. In J. Ramos, D. Bernal, \& V. Castañeda (Eds.), El Abrigo y la Cueva de Benzú en la Prehistoria de Ceuta. Consejería de Educación y Cultura de Ceuta, UNED Ceuta y Servicio de Publicaciones de la Universidad de Cádiz.

Morales, J., Pérez-Jordá, G., Peña-Chocarro, L., Zapata, L., RuízAlonso, et al. (2013). The origins of agriculture in NorthWest Africa: Macro-botanical remains from Epipalaolithic and Early Neolithic levels of Ifri Oudadane (Morocco). Journal of Archaeological Science, 40, 1659-1669.

Morales, J., Pérez-Jordá, G., Peña-Chocarro, L., Bokbot, Y., Vera, J. C., et al. (2016). The introduction of South-Western Asian domesticated plants in North Western Africa: An archaeobotanical contribution from Neolithic Morocco. Quaternary International, 412(Part B), 96-109.

Nekkal, F. (2015). La genèse du néolithique dans la région du Rif oriental: Contexte chronostratigraphique et culturel. Ph.D. dissertation, Université Mohammed I, Oujda.

Raissouni, B., Bernal, D., El Khayari, A., Ramos, J., \& Zouak, M. (Eds.) (2015). Carta Arqueológica del Norte de Marruecos (2008-2012). Prospección y yacimientos, un primer avance. Vol. I. Editorial UCA, INSAP, Universidad Abelmalek Essaadi. Cádiz.

Ramos, J., \& Bernal, D. (Eds.). (2006). El Proyecto Benzú 250.000 años de historia en la orilla africana del Círculo del Estrecho. 30 preguntas y 10 opiniones. Cádiz: Ciudad Autónoma de Ceuta y Servicio de Publicaciones de la Universidad de Cádiz.

Ramos, J., \& Cantillo, J. J. (2009). Los recursos litorales en el Pleistoceno y Holoceno. Un balance de su explotación por las sociedades cazadoras-recolectoras, tribales comunitarias y clasistas iniciales en la región histórica del Estrecho de Gibraltar. In D. Bernal (Ed.), Arqueología de la Pesca en el Estrecho de Gibraltar (pp. 17-80). Cádiz: Servicio de Publicaciones de la Universidad de Cádiz.

Ramos Muñoz, J., Bernal Casasola, D., Vijande Vila, E., \& Cantillo, J. J., Eds. (2013). El abrigo y la cueva de Benzú. Memoria de los trabajos arqueológicos de una década en Ceuta (2002-2012). Ciudad Autónoma de Ceuta, Servicio de Publicaciones de la Universidad de Cádiz.

Ramos, J., Bernal, D., \& Castañeda, V. (Eds.). (2003). El Abrigo y Cueva de Benzú en la Prehistoria de Ceuta. Aproximación al estudio de las sociedades cazadoras-recolectoras y tribales comunitarias en el ámbito norteafricano del Estrecho de
Gibraltar. Cádiz: Ciudad Autónoma de Ceuta, UNED y Servicio de Publicaciones de la Universidad de Cádiz.

Ramos, J., Bernal, D., Raissouni, B., Zouak, M., El Khayari, A., et al. (2011). Informe de la campaña del año 2011 del proyecto de investigación. Carta Arqueológica del norte de Marruecos Excavaciones en el exterior 2011. Informes $y$ trabajos, 9, 488-525.

Ramos, J., Zouak, M., Vijande, E., Cabral, A., Gutiérrez, J. M., et al. (2015). Novedades en el registro arqueológico de las sociedades tribales neolíticas del Norte de Marruecos. In V. S. Gonçalves, M. Diniz, \& A. C. Sousa (Eds.), Actas del V Congreso do neolítico peninsular (pp. 349-358). Lisboa: Centro de Arqueología da Universidades de Lisboa.

Ramos-Muñoz, J., Bernal, D., Domínguez-Bella, S., Calado, D., Ruiz, B., et al. (2008). The Benzu rockshelter: A Middle Palaeolithic site on the North African coast. Quaternary Science Reviews, 27, 2210-2218.

Ramos-Muñoz, J., Bernal-Casasola, D., Barrena-Tocino, A., Domínguez-Bella, S., Clemente-Conte, I., et al. (2016). Middle Palaeolithic Mode 3 lithic technology in the rockshelter of Benzú (North Africa) and its immediate environmental relationships. Quaternary International, 413, 21-35.

Ramos-Muñoz, J., Zouak, M., Almisas-Cruz, S., Barrena-Tocino, A., Domínguez-Bella, S., et al. (2018). Abrigo y cueva de Marsa. Un nuevo depósito estratigráfico con arte rupestre prehistórico en el Norte de Marruecos. In Actas del Congreso La Mauritanie et le monde Méditerranéen (pp. 178-193). Publications de la Faculté des Lettres et Sciences Humaines. Université Abdelmalek Es Saadi. Tétouan.

Raynal, J. P. (2008). Mission préhistorique et paléontologique française "Littoral"Maroc. Rapport sur la campagne 2008 et prospective, 2009-2011.

Ruiz-Gálvez, M., De La Peña, P., De Torres, J., Bokbot, Y., Madi, M., et al. (2012). In I. Argerich, F. Benito, A. Carrassón, S. Díaz, A. Domingo, et al. (Eds.), Informes y trabajos, 9. Excavaciones en el exterior 2011 Cuarta campaña de campo en Oukä̈meden (Alto Atlas) y nuevos datos sobre la gestión de recursos críticos en un tipo de valle alpino en la Prehistoria (pp. 470-489). Madrid: Ministerio de Educación, Cultura y Deporte.

Soriguer, M. C., Zabala, C., \& Hernando, J. A. (2006). ¿Recogieron moluscos y peces? In J. Ramos \& D. Bernal (Eds.), El Proyecto Benzú. 250,000 años de Historia en la orilla africana del Círculo del Estrecho. 30 preguntas y 10 opiniones (pp. 127-130). Cádiz: Ciudad Autónoma de Ceuta y Servicio de Publicaciones de la Universidad de Cádiz.

Tarradell, M. (1954). Noticia sobre la excavación de Gar Cahal. Tamuda II, 344-358.

Tarradell, M. (1958a). Kaf Taht el Gar, cueva neolítica en la región de Tetuán (Marruecos). Ampurias, 19-20, 137-166.

Tarradell, M. (1958b). Sobre el Neolítico del noroeste de Marruecos y sus relaciones. Tamuda, 6(2), 279-305.

Thiébault, S. (1988). L'Homme et le milieu vegetal. Analyse anthracologique de six gisements de pré-Alpes au Tardiglaciaire et au Postglaciaire. Documents d'Archéologie Française, 15. Maison des Sciences de l'Homme, París.

Uzquiano, P. (1992). Recherches anthracologiques dans le secteur Pyréneo-cantabrique (Pays Basque, Cantabria et Asturias): Environnements et relations homme-milieu au Pléistocene supérieur et debut de 1- Holocène. Thèse Université de Montpellier II. Montpellier. 
Uzquiano, P. (1997). Antracología y métodos: Implicaciones en la economía prehistórica, etnoarqueología y paleoecología. Trabajos de Prehistoria, 54(1), 145-154.

Uzquiano, P. (2000). El aprovechamiento del bosque durante el Tardiglaciar y el Holoceno en la Cuenca de Arudy (Pirineos occidentales, Francia). Complutum, 11, 143-156.

Uzquiano, P. (2002). Vegetation and firewood management at Cueva de la Vaquera (Segovia, Spain) between 6-3.7 kyrs. BP: Anthracological contribution to the landscape archaeology of the Spanish Central Mountains. British Archaeological Reports International Series 1063. Oxford: Archaeopress.

Uzquiano, P. (2006). ¿Qué es la Antracología? Métodos de muestreo, análisis e interpretación de las maderas carbonizadas en Prehistoria. Aplicación al estudio de los carbones de Benzú. In J. Ramos \& D. Bernal (Eds.), El Proyecto Benzú 250.000 años de Historia en la orilla Africana del Círculo del Estrecho. 30 preguntas y 10 opiniones (pp. 109-115). Ciudad Autónoma de Ceuta y Servicio de Publicaciones de la Universidad de Cádiz.

Uzquiano, P. (2008). Resultados antracoanalíticos de la ocupación neolítica de Benzú (Ceuta). Comunidades vegetales y aprovechamiento. In M. Hernández, J. Soler, \& J.A. López Padilla (Eds.). $I V^{\circ}$ Congreso del Neolítico en la Península Ibérica. Tomo I (pp. 374-379). MARQ. Diputación Provincial de Alicante. Alicante.

Uzquiano, P., \& Arnanz, A. M. (2002). Estudio arqueobotánico del asentamiento de 'El Retamar' (Puerto Real, Cádiz). In J. Ramos \& M. Lazarich (Eds.), Memoria de la excavación arqueológica en el asentamiento del VI milenio a.n.e. de 'El Retamar' (Puerto Real, Cádiz) (pp. 101-103). Sevilla: Arqueología Monografías, Junta de Andalucía.

Uzquiano, P., \& Zapata, L. (2000). Vegetación y subsistencia durante la Edad del Bronce en el Cantábrico oriental: La cueva de Arenaza (S. Pedro de Galdames, Bizkaia). In V. Jorges (Ed.), Actas do $3^{\circ}$ Congresso de Arqueología
Peninsular vol. 9 (pp. 51-68). Porto: Contributos das Ciências e das Tecnología para a Arqueología da Península Ibérica.

Vijande, E. (2010). Formaciones sociales tribales en la región histórica del Estrecho de Gibraltar (VI-IV milenios a.n.e.). Los ejemplos de la Cueva de Benzú (Ceuta) y el asentamiento de Campo de Hockey (San Fernando, Cádiz). Tesis Doctoral Inédita. Universidad de Cádiz, Cádiz, Spain.

Vijande, E. (2011). La Cueva de Benzú: Aportaciones al estudio de las sociedades tribales en el Holoceno. In J. Ramos, D. Bernal, A. Cabral, E. Vijande, \& J. J. Cantilllo (Eds.), Benzú y los orígenes de Ceuta (pp. 59-74). Ceuta: Ciudad Autónoma de Ceuta, Museo de la Basílica Tardorromana de Ceuta y Universidad de Cádiz.

Vijande, E., Ramos, J., Bernal, D., Pérez, M., Clemente, I., Zurro, D. (2008). Cueva de Benzú (Ceuta). Nuevas aportaciones al estudio de las sociedades tribales en el área norteafricana del Estrecho de Gibraltar. In M. Hernández, J. Soler, \& J. A. López (Eds.), IV Congreso del Neolítico Peninsular, (pp. 379-384). MARQ. Diputación Provincial de Alicante. Alicante.

Vijande, E., Cantillo, J. J., Cabral, A., Ramos, J., Bernal, A., \& Barrena, A. (2011). Benzú en su territorio. In J. Ramos, D. Bernal, A. Cabral, E. Vijande, \& J. J. Cantillo (Eds.), Benzú y los orígenes de Ceuta (pp. 59-74). Ceuta: Ciudad Autónoma de Ceuta, Museo de la Basílica Tardorromana de Ceuta y Universidad de Cádiz.

Wengler, L., Delibrias, G., Michel, P., \& Vernet, J.-L. (1989). Sites néolithiques du Maroc oriental: Cadre chronologique, archéologie et milieu naturel. L'Anthropologie, 93(4), 507534.

Publisher's Note Springer Nature remains neutral with regard to jurisdictional claims in published maps and institutional affiliations. 